\title{
Sinemada Dijital Görsel Efekt Kullanımı Ve Alternatif Gerçeklik Kurgusu
}

\author{
Vedat Güntay* \\ Gamze Y1lmaz Güntay**
}

\section{$\ddot{O} z e t$}

Hayat kendi gerçekliğini kurgularken insan zihni, farkh oluş biçimleri geliştirerek gerçeklik algısını değişime uğratabilmektedir. Değişmez olarak nitelendirilen fizik kuralları yeni formlara sokulabilmekte ve bu kurallar üzerinde oynamalar yapan bakış, kendi değişimli yasalarını oluşturabilmektedir. İnsan oluş hallerini farklı perspektiflerle ortaya koyan sinema önemli bir ifade biçimi olarak kullanılmakla birlikte, teknolojik gelişmeler sinema sanatçılarına kendilerini ifadede çok seçenekli bir alan oluşturmaktadır. Teknolojinin yaratıcı beyinlere sunduğu olanaklar, sinemanın bugünkü çehresini değiştirmiştir. Bugün sinemada yoğun olarak kullanılan dijital görsel efekt uygulamalar ile günlük hayatta deneyimlenmemiş, yeni hayali evrenler ve karakterler yaratılmıştır. Yaratıcıliğın sinırlarını esneten, hatta ortadan kaldıran dijital görsel efekt uygulamaları sinema anlatısina farklı boyutlar katarak yeni hikaye alanları oluşturmuştur. Evrenin ve zamanın sonsuz çokluğuna doğru yol alınırken sinemanın döngüsel yapısını kesintiye uğratan bu uygulamalar, gerçekliğe dair net olduğunu düşündüğümüz tanımlarımızı sorgulatan anlatıların görselleştirilebilmesine olanak sağlamaktadır. Böylece farklı olasılıkların ortaya konulabilmesiyle sinema filmlerinde edimsel dünyada duyulamayanlar duyulabilir, görülemeyenler görülebilir, hissedilemeyenler hissedilebilir olmaktadır. Deleuze'ün 'zaman imaj' kavramı üzerinden irdelenen çalışmada, çok boyutlu oluş hali ve hareketi takip eden zamanın dışına taşan, hayallerde, düşlerde, gerçekliğin yeni boyutlarnda, paralel evrenlerde dans eden anlatımlar geliştiren filmler incelenmiştir. Sinema filmlerinde görsel efekt kullanımıyla kurgulanan alternatif gerçeklik biçimleri okunmaya çalışılmıştır.

Anahtar Kelimeler: Sinema ve Gerçeklik, Dijital Görsel Efekt, Zaman İmaj

ORCID ID : 0000-0003-1982-5910 \& 0000-0003-1763-5208

E-mail : vedatguntay@gmail.com; gamzeguntay@gmail.com

DOI: $10.31122 /$ sinefilozofi.513304

Geliş Tarihi - Recieved: 16.01.2019

Kabul Tarihi - Accepted: 25.04.2019 


\title{
The Usage Of Digital Visual Effects İn Cinema And Alternative Reality Fiction
}

\author{
Vedat Güntay* \\ Gamze Yılmaz Güntay**
}

\begin{abstract}
While life is constructing it's own reality, the human mind can change the perception of reality by developing different forms of being. The laws of physics, which are described as unchangeable, can be introduced into new forms and the view that plays on these rules can create their own laws of change. Although cinema is used as an important form of expression which presents human being with different perspectives, technological developments are an area of choice for cinema artists to express themselves. The possibilities of technology to creative minds have changed the face of cinema today. Today, Digital Visual Effects applications that are widely used in cinema have not been experienced in everyday life, and new imaginary universes and characters have been created. Digital Visual Effects practices that stretch the boundaries of creativity and even eliminate them have created new story areas by adding different dimensions to the narrative of cinema. These practices, which interrupt the circular structure of cinema as they travel towards the infinite abundance of the universe and time, allow visualisation of the narratives that question our definitions of reality that we think are clear. Thus, with the possibility of introducing different possibilities, the ones that can not be heard in the virtual world can be heard, the ones who can not be seen can be seen, and the ones who can not be felt can be felt. In this study, the concept of "time image" of Deleuze is examined, the multidimensional state and the motion that goes beyond the following time, the dreams, dreams, new dimensions of reality, the parallel universes of the films that develop dance expressions. Alternative forms of reality that were created with visual effects in films were tried to be studied.
\end{abstract}

Keywords: Cinema and Reality, Digital Visual Effects, Time Image

ORCID ID : 0000-0003-1982-5910 \& 0000-0003-1763-5208

E-mail : vedatguntay@gmail.com; gamzeguntay@gmail.com

DOI: 10.31122/sinefilozofi.513304

Recieved - Geliş Tarihi: 16.01.2019

Accepted - Kabul Tarihi: 25.04.2019 


\section{Giriş}

Günlük sıradan yaşantımız içinde bir sorunla karşılaştığımızda düşünmeye, sorular sormaya ve sorularımıza anlamlı yanıtlar aramaya başlarız. Bu yantlar bazen beraberinde yeni soruları getirirken bazen de doğru olduğuna karar kıldığımız yanıtların zaman içinde geçerliliğini yitirdiğini görürüz. Genellikle olay ve durumlara farklı perspektiflerden bakar ve bir değil birden çok bilinmeyenle karşılaşırız. Varlığı boyunca insanoğlu, soru ve yantlarla örülü bir anlamlandırma mekanizması geliştirmektedir diyebiliriz. İçinde yaşadığı evreni anlamaya, anlamlandırmaya çalışan her disiplin farklı yol ve yöntemlerle sorduğu soruların yanıtlarının izini sürmektedir. Bu bağlamda Bergson ve Deleuze'ün de altını çizdiği gibi, felsefe kavramlarla yol alırken, bilim fonksiyonlarla hareket eder. Sanat ise kendi içkin nitelikleriyle yarattığı duyumlar aracılığıyla anlamı oluşturmaktadır. Örneğin resim sanatı renkler, 1şık ve çizgilerle anlamı oluştururken, müzik melodilerle, sinema ise hareketli görüntülerle anlatısını inşa etmektedir. Bu doğrultuda bilim, sanat ve felsefe ayrı disiplinler de olsa bazı ortak sorulara kendi lisanlarında yanıt aramaktadırlar. "Gerçeklik" de bu disiplinlerin üzerine düşündükleri ve çalıştıkları kavramlar arasındadır. Mutlak bir gerçeklikten söz edebilir miyiz? Gerçeklik ideolojik olarak mı inşa edilmiştir? Durduğumuz yer ve yön baktığımız nesne, olay ya da durumun gerçekliğini değiştirir mi? Bilimsel olarak kanıtlanmadığı sürece mutlak anlamda bir gerçekten bahsedilemez mi? Bilimsel olarak mutlak kabul edilen gerçekler zamanla yeni bilgilerin edinilmesiyle gerçekliğini yitirebilir mi? Bugün bilgisine sahip olmadığımız şeylerin gerçek olmadığını iddia edebilir miyiz? İçinde bulunduğumuz, ekonomik, sosyal, kültürel, fiziksel ya da ruhsal durum "gerçekliği" diğerlerinden farklı boyutlarda görmemize neden oluyorsa, gördügüüüzü ya da hissettiğimizi gerçek olarak kabul edemez miyiz? Tek bir gerçek yerine çoklu gerçekliklerden sözedebilir miyiz? "Gerçek" kavramının kendisi mi problemlidir? Bu ve benzeri pek çok soru üzerine düşünmekte olan bilim, felseve ve sinema, bu soru ve yanıtları kendi araçlarıyla ortaya koymaktadır. Bununla birlikte disiplinlerarası etkileşimli bir süreçten de bahsedilebilmektedir. Yani bütün bu disiplinler birbirlerinin çalışmalarını etkileyebilmektedir.

Bazin, “Tabiatıyla 'Gerçek', bir nicelik olarak anlaşılmamalıdır. Aynı olay, aynı nesne değişik yollardan ortaya konabilir" demektedir. (1966: 161). Bizim duyarlılığımızın dışında kendi başına var olan şeyin madde olduğunu, oysa gerçekçiliğin insanın yaşantı ve anlayış yeteneğiyle katılabileceği sayısız ilişkileri kapsayacağını söyleyen Fischer'a göre "gerçekliğin bütünü, özne ve nesne arasındaki bütün ilişkilerin toplamıdır; yalnız geçmişteki değil, gelecekteki ilişkilerin; yalnız olayların değil, bireysel yaşantıların düşlerin, sezgilerin, heyecanların, hayallerin toplamıdır" (1990: 95-96). "Bilimsel gerçeklik" kavramı üzerinde durduğumuzda ise, Eistein'in "İzafiyet teorisi" (görelilik kuramı) çerçevesinden bakacak olursak, fiziksel gerçeklik olarak ortaya koyabileceğimiz hareketin varlığı ve yokluğu, yani bir cismin hareket edip etmediği bile hangi konumdan bakıldığına göre değişebilmektedir. Einstein'a göre her gözlemci bulunduğu konum bağlamında aynı oranda haklıdır, yani gerçeklik izafidir.

Nesnel denilen bilimsel gerçekliğin bile izafi olduğu ve bakış yönüne göre değişebileceği düşüncesinden hareket edildiğinde, sanatın kendi gerçekliğini inşa ettiği kabulünden sinema perdesinden yansıtılan varoluş biçimlerine bakıldığında, sinemanın dizayn ettiği gerçeklik üzerine düşünmek, bu hususta ortaya konulmuş çeşitli yaklaşımların irdelenmesini zorunlu kilmaktadir. 
Sinemanın ilk yıllarından itibaren "gerçeklik" kavramı, filmler üzerine düşünen akademik ve kuramsal yaklaşımların incelediği konular arasında olmuştur. Lumière kardeşlerin 1895 yılında, Paris'te bir kafede, fabrikadan çıkan işçiler, trenin gara girişi, bir ailenin öğle yemeği gibi günlük hayattan gerçek görüntüleri yansıttıkları gösterimle birlikte, sinemada gerçeklik tartışmalarının başladığını söyleyebiriliriz. Bunun yanı sıra Lumière kardeşlerin, gerçek yaşamdaki görüntüleri aktardığı filmlerden oldukça farklılaşan ve ilk bilim kurgu filmi olarak anılan “A Trip to the Moon" (Aya Seyahat, 1902), Georges Méliès'in sihirbazlık geçmişisinin avantajlarından yararlanarak, pek çok özel efekt kullanmış olduğu, biçimsel özellikleriyle kendi gerçekliğini yaratan bir film olarak sinema tarihine geçmiştir. Butler' in ifadesiyle, "Film, bir yandan Lumière'nin sokaklarda, dükkanların çevresinde çektiği filmlerde olduğu gibi, gerçekliğin betimlenmesi olabilirken, bir yandan da Fransız sihirbaz Georges Méliès tarafından çekilen filmlerde olduğu gibi, kendi gerçekliğini yaratmaya da kalkışabilir" (2011: 16). Bu iki filmden yola çıkarak sinema tarihinin ilk yılları incelendiğinde gerçekçilik ve biçimcilik tartışmaları üzerinden kuramların inşa edilmiş olduğu görülmektedir.

Hugo Munsterberg, Rudolf Arnheim, Vsevolo Pudovkin, Sergei Eisenstein, Bela Balazs olarak sıralayabileceğimiz biçimci gelenek temsilcileri, sanatın tanımlamaya çalıştığı gerçekliğin "biçimsel” açıdan yorumlanması üzerinde durmuşlardır (Büker ve Topçu, 2010: 61). Eisenstein için, kurgulanmamış filmin parçaları gerçekliğin mekanik yeniden üretiminden fazlası değildir. Sadece montaj modelleri içinde düzenlendiğinde film sanat olur. Eisenstein montajı; filmin parçalarını, "gerçekliğin parçaları" olmaktan sanata dönüştüren düzenleme olarak görür (Yılmaz, 2011: 26). Sinemanın sanat olabilmesi için gerçekle ilişkisini kesmesi gerektiğini iddia eder. Ona göre sinemayı sanat yapan, belirlenen perspektiflerden çekilen özgün görüntülerin montaj yoluyla yeniden kurgulanması ve kendi özgün anlamını oluşturmasıdır. Arnheim da benzer şekilde sinema filminin sanat olabilmesi için nesnel gerçeklikten uzaklaşması gerektiğini söylemektedir.

Siegfried Kracuer, Andre Bazin gibi gerçekçi gelenek temsilcileri ise sinemanın "gerçekliği yeniden üretme" özelliğini ön plana çıkarmaktadırlar (Büker ve Topçu, 2010: 61). Gerçekçi gelenek, sinemanın sanat olduğunu söylerken sinemanın gerçeğin derin yapısını ortaya çıkarmaya çabaladığını ve "gerçeğe hiçbir şey eklemediğini", onun "biçimini bozmadığını" savunur. Bazin'e göre sinema nesnelerdeki gizli anlamı ortaya çıkarır. Duyularla algılayamadığımız gerçekliği verir. Çünkü doğaya, nesnelere dilediğince yaklaşır. Bazin, kurgunun yerine uzun çekimleri ve alan derinliğini tercih ederken içeriğin gerçekliği üzerinde durmaz. Sinemada önemli olan uzamsal gerçekliktir. Film nesneyi yer aldığı uzam içinde verir. Bazin'e göre sinemanın hammaddesi "gerçeklik" değil, "gerçekliğin bıraktığ1 iz" dir (Akt. Büker, 1989: 19-20). Gerçek, sanat değildir, ama "gerçekçi" bir sanat, gerçeğin tamamlayıcısı olan bir estetik yaratmasını bilen sanattır (Bazin, 1966: 79). Andre Malraux ise sinemayı, plastik gerçekliğin ileri evrimi olarak tanımlamıştır (Akt. Bazin, 2013: 16).

Yılmaz'a göre, sinemada "gerçeklik" üzerine düşünen kuramcılar, ne gerçeği tanımlar ne de gerçeğe dair herhangi bir kuram geliştirirler (2011: 21). İki kuramsal yaklaşım da "gerçek" kavramının kendisi üzerinde durmadan tezlerini üretirken, gerçekliğin ne olduğu hakkında düşünmek yerine sinemada gerçekliğin nasıl işlediğini ele almışlardır.

Pek çok film, dünya gerçekliğine yeni ve farklı perspektiflerle bakabilmemizi sağlayan anlatılar geliştirmektedir. Bu çalışmada, nesnel gerçeklik kavramının kendisini sorgulayan ve bireyin iç dünyasının izleriyle yeniden inşa edilen gerçekliği gündeme getiren Big Fish 
(Büyük Balık, Tim Burton, 2003), Life of Pi (Pi'nin Yaşamı, Ang Lee, 2012) gibi filmlerin yanı sıra; toplumsal yaşam içinde güç-iktidar ilişkileri bağlamında, ideolojik olarak inşa edilen gerçekliğin yapı bozumuna uğratıldığı Avatar (James Cameron, 2009) filmi ve gerçek dünya ile rüya aleminin arasındaki sınırın muğlaklaştığı İnception (Başlangıç, Christopher Nolan, 2010) filmi ele alınmıştır. Belirlenen filmler, dijital görsel efekt uygulamalarının hikayedeki anlamı oluşturmak ya da desteklemek için kullanıldığı filmler arasından seçilmiştir. Bu çalışmada görsel efekt kullanımının, gerçeklikle ilgili algılarımız üzerinde nasıl bir etki yarattığı ve filmlerin kendi sanatsal gerçekliğini nasıl oluşturduğu incelenmiştir. Kristalleşen zamanlarda, yani rasyonel düşünceden uzaklaşılarak irasyonel düşünceyi yaratan, hayali ve düşsel zamanlarda, filmlerin kendi gerçekliğini üreten anlatı yapısı üzerinde durulmuş ve bu anlatı yapısının şekillenmesinde görsel efekt kullanımıyla yaratılan karakter ve evrenler incelenmiştir. Farklı bir ifadeyle ortaya koyacak olursak, rasyonel olan gerçeklik, irasyonel gerçeklik ile birlikte ya da iç içe geçmiş olarak ele alınmıştır.

\section{Sinemada Görsel Efekt Kullanımı ve Gerçeklik Algısı}

Görsel efekt terimi, sanat ve tasarım alanlarıyla bilim ve teknolojiyi birleştiren bir yöntem olarak, uzun yıllardır bilinmektedir. Özellikle sinemadaki kullanımı ve etkilerine bakıldığında, bilgisayarın icadı ve gelişmesi sonrasında, optik yani analog makinelerin bu alanda kullanılması ile ortaya çıkmıştır. 1980'li yıllar ve sonrasında ise yapılan dijital çalışmalarla, sinema anlatısında tamamen yeni bir dönem başlamıştır. Beden ve mekan anlayışının boyut değiştirdiği günümüz toplumlarında, hayal gücünün sınırlarını zorlayan anlatılar, bugün artık sanal ortamda oluşturulan tasarımlarla var edilebilmektedir. Bu bağlamda bilim kurgu ve animasyon filmlerinden televizyon dizilerine, belgesel filmlerden reklam filmlerine, oyun tasarımlarından yeni medyaya kadar bir çok alanda yararlanılan dijital görsel efekt çalışmalarının etkin bir şekilde kullanıldığı görülmektedir (Güntay, 2018: 1).

Sinemada görsel efekt kullanımı ve değişen film yapım süreçlerinden sözetmeden önce "özel efekt" ve "görsel efekt" ayrımının yapılması önemlidir. Bu farklılığa dikkat çeken Dinur'a göre, görsel efektlerin bilgisayarlaştırıldığ1 dijital dönem öncesinde, birçok efekt, çekim mekanında kullanılan minyatürler, pratik teknikler ve çeşitli kamera optik yanılsamalarıyla yapılmaktaydı. Ortada açık bir şekilde özel ve görsel efekt tasarımı ayrımı yoktu. Ancak günümüzde bu iki terim, birbirinden çok ayrı iki sanatı tanımlamak için kullanılmaktadır. Dinur'un tanımıyla özel efektler, pratik olarak gerçek hayatta set üzerindeki uygulanmış efektlerin kamera tarafından kayıt altına alınmasıyla elde edilirken; görsel efektler ise görüntünün dijital ortamdaki manipülasyonu ile yapım sonrası aşamasında gerçekleştirilmektedir (2017: 7). Benzer şekilde görsel efekt tasarımını, "görüntünün manipüle edilmesi, değiştirilmesi” olarak niteleyen Wright'a göre bu yöntem, sahne içerisinde çekilmesi imkansız, zor ya da maliyetli görsel unsurları bilgisayar yardımıyla kompozisyon içerisine post-prodüksiyon esnasında yerleştirme, çıkartma ya da ekleme işlemidir (2008: 1-2). Kısaca, görsel efekt terimini, kameraya alınan gerçek görüntüyle bilgisayar ürünü görüntünün (CGI) birleştirilmesi işlemi olarak da ifade edebiliriz.

Özellikle bilişim sektöründeki teknolojik gelişmelerin tasarımcılara sunduğu olanaklar, sinemanın bugünkü çehresini değiştirmiştir. Dijital görsel efekt uygulamaları, gerçek hayatta karşılaşılması mümkün olmayan hayali evrenler ve karakterler yaratmıştır. Olanakların sınırlarını esneten ve genişleten nitelikte hikayeler oluşturulmasının zeminini hazırlamıştır. Son dönemde sinema filmlerinde dijital ortamlarda yaratılan mekansal tasarımlarla insan 
zihninin deneyimlerini aşan yeni yaşam alanları oluşturulmaktadır. "Avatar" filminde olduğu gibi havada asılı duran devasa ağaçlarla kaplı dağlar ve 1şık saçan bitkilerle inşa edilmiş hayali evrenler kurgulanarak doğal yaşamın güzelliklerine ve insanoğlunun yıkıcılığına vurgu yapılabilmektedir. Bir başka örnek, "Interstellar" filminde, tamamen buzullardan oluşmuş veya devasa dalgaların başka hiçbir varlığa yaşam alanı bırakmadığı tamamı sularla kaplı gezegenler var edilmekte; hatta zamanın akışı içinde karakterin hapsolduğu farklı boyutlarda alanlar yaratılarak evrenin ve zamanın sonsuz çokluğuna vurgu yapılabilmektedir.

Günümüzde yeni teknolojilerle geliştirilen ve zenginleştirilen dijital görsel efekt tasarımları aracılığıyla, önceleri görselleştirilmesi olanaksız olarak ifade edilen pek çok hikaye ya da anlatı bugün sanatçıların yaratıcılığın sınırlarını zorlayan tasarımlarında görselleştirilebilmektedir. Dijital görsel efekt uygulamalarıyla filmlerde altı çizilerek vurgu yapılmak istenen bağlamlar, izleyici kitlenin zihninde belirginleştirilmekte ya da sinema filmlerinin döngüsel yapısı kesintiye uğratılabilmektedir. İyiye, kötüye, doğru ve yanlışa dair net olduğunu düşündüğümüz tanımlarımızı sorgulatan anlatıların görselleştirilebilmesine olanak sağlayan yeni formlar ve boyutların üretilebilir hale gelmesi, sinema filmlerinde farklı olasılıkları da gündeme getirmiştir (Güntay, 2018: 2-3).

“Beyaz perdede geçen olay ne kadar gerçekdışı olursa olsun, seyirci buna tanık olur ve deyim yerindeyse olaya katılır" ifadesini kullanan Lotman, bu nedenle, seyircinin olayların gerçek olmadığını bilmesine karşın sanki gerçekmiş gibi duygusal bir biçimde tepki gösterdiğinin altını çizmektedir (2012: 23). Bu bağlamda özellikle Hollywood yapımı filmlerde, Lotman'ın işaret ettiği şekilde, seyircinin filmin gerçek olmadığını bilse de anlatıya inanması ve gerçekmiş gibi duygusal tepki vermesi hedeflenmektedir. Bu nedenle bilsiyar ürünü görüntü tasarımında, gerçeğe yakınlık, inandırıcılığı artırmak için yapımcılar ve dolayısıyla tasarımcılar tarafından önemsenen bir unsurdur (Güntay, 2018: 36). Dinur, görsel efekt tasarımındaki gerçekçilik arayışının, filmin kendisinin gerçek olmadığı düşüncesinden yola çıkarak paradoksal olduğunun altını çizmektedir. Bununla birlikte yazara göre kurgusal filmler her ne kadar gerçek değilse bile, kameranın gözünde gerçektir. Bir başka deyişle kamera tarafından yakalanan görüntü varsayılan bir biçimde foto-gerçekçidir. Görsel efekt tasarımı ise gerçek değildir. İşte bu nedenle görsel efekt tasarımı sanatçıları sürekli olarak yaptıkları çalışmaların daha foto-gerçekçi olmasını mümkün kılmak için çabalamaktadır. Dinur foto-gerçekçiliğin, görüntü üzerinde yapılanların gerçekçi bir şekilde tasarlanarak düzenlenmesi olduğunu vurgulamaktadır. (2017: 12). Mitchell'e göre ise bir anlamda başarılı bir görsel efekt tasarımı oluşturmak, kuralları yıkarak değiştirilmiş bir gerçekliği göstermektir. Böylece izleyicilerin algısı manipüle edilerek inanmamalarının önüne geçilmiş olur. Görsel efekt tasarımı, uygulayıcıların, dijital yöntemleri anlayarak doğru görüntüleri üretmelerini ve gerçeğin aynı ya da en azından gerçeğe yakın görüntüler oluşturmalarını gerektirir. (2006: 9)

Teknolojik gelişmeler her alanda olduğu gibi sanat ve tasarım alanında da belirleyici rol oynamaktadır. İnsan zihninin yaratım gücü, yeni teknolojiler aracılığıyla farklı boyut ve formlarda ifade alanları oluşturabilmektedir. Bu sayede dünün hayal ürünü imajları bugünün gerçekliğini oluşturur hale gelebilmekte ya da zihnimizde var olan ama form vermekte zorlandığımız düşünce ve anlatılar bu teknolojiler sayesinde görünür hale gelmektedir (Güntay, 2018: 189). Sinema filmlerinde kullanılan teknolojiler, hikaye anlatımında ve anlamın oluşturulmasında önemli katkılar sağlamaktadır. Dijital uygulamaların yoğunlaştırıldığı filmlerin gişe rekorları kırması, aynı zamanda bir endüstri ürünü olan sinema filmlerinde 
görsel efekt kullanımının artmasına yol açmıştır. Ancak burada üzerinde durulması gereken temel nokta, son dönemde üretilen pek çok yapımda efekt kullanımının filmde inşa edilmeye çalışılan anlamın da önüne geçtiğidir. Bu nedenle bugün sinema sektöründe kullanılan dijital görsel efektleri iki düzeyde ele almak gerekmektedir. İlki anlamı destekleyecek şekilde geliştirilen efekt kullanımı; ikincisi ise hikayenin ve anlamın önüne geçen yoğunlaştırılmış efekt kullanımıdır. Bu çalışma kapsamında incelenen filmler belirlenirken, özellikle ilk yaklaşımda olduğu gibi hikaye anlatımını destekleyen ve anlamın inşasına katkı sağlayan dijital görsel efektlerin kullanıldığı filmler tercih edilmiştir.

\section{Gerçeklik Kavramının Sinemada Hareket ve Zaman İmajlar Üzerinden Okunması}

Her sanat türünde olduğu gibi sinema da kendi içinde evrilerek değişmekte ve varlıkların oluş hallerini yansıtırken zaman içinde farklı yaklaşımlar geliştirmektedir. $\mathrm{Bu}$ yaklaşımlar film yapım süreçlerini, anlamın inşasını ve nasıl okunduğunu etkilerken Deleuze bu değişimi "hareket imaj" ve "zaman imaj” ayrımıyla ortaya koymaktadır. Kabadayı' ya göre Deleuze, hareket imaj ve zaman imaj ile böldüğü sinema anlayışı aracılığıyla, klasik sinema ile modern sinema arasındaki kırılmayı da tanımlama arayışında olmuştur (2013: 53). Klasik dönem sinemasında harekete bağlı bir akışın izleri sürülürken modern sinemada, zamanın harekete bağlı okunuşu ilkesi değişmektedir.

Deleuze, zaman imgesinde, zamanın doğrudan imge olarak verilişini art arda gelişle açıklayamayacağımızı belirtir. Çünkü artık zamanın devreye girmesiyle hareket, sinemanının ilk dönemine ait hareketten farklı olan ve değişim temelinde zamanın saf biçimi olan 'oluşum'u gerektiren harekettir. (Akt. Sütçü, 2005: 155) Zaman-imaj, mekanda sürekli hareket eden bedenler yerine, rüyalarında, hafızalarında, ima edilmiş bir düş gibi olan dünya hareketlerinde, gündüz düşlerinde içsel zamanlarında yolculuk yapan ve virtüel ile edimselin birbirine karıştığı kararsızlık anlarını içerir. (Öztürk, 2018: 353). Böylece bireyin duyguları ve varoluş biçimleri daha görünür bir form alır. Hayallerin, düşlerin yansıtılabilir olması mutluluk, korku, endişe, nefret, haz gibi duyguları ortaya çıkartır. Kabadayı'nın ifadesiyle "Sinema, toplumun genelinin düşlerini, mitlerini ve korkularını kristalize eder" (2013: 76). Deleuze' ün "zaman imajlar" olarak nitelediği, hareketin ötesine geçip zihnin derin sularında salınan bir anlatım biçimi geliştirilmesiyle, bu filmlerde gerçekliğin sadece fiziksel dünyanın gerçekliğini yansıtmadığını; rüyalardaki, hayallerdeki, düşüncedeki gerçeklikle genişleyen bir anlatım biçimi geliştirildiğini söyleyebiliriz. Dijital teknolojilerin gelişmesiyle bu bağlamda zihinsel gerçekliğin dışavurumu önündeki engeller aşılmış ve gösterilemez olan hayalgücünün ya da düşlerin evreni görünür hale gelmiştir.

Sinema filmlerinin yapım biçimlerine ve anlamı inşa formlarına baktığımızda, bugün gelinen noktada hareket imaj ve zaman imaj olarak yapılan bu ikili ayrımın her film için belirgin sınırlarla oluşturulamadığının altını çizmemiz gerekmektedir. Hem hareket imaj hem de zaman imajın izlerini taşıyan filmlerle karşılaşabilmektedir izleyici. Belli bir bütünlük içinde oluşturulan geçişli anlatılar, ana karakter ya da kahramanla özdeşim kurulmasını sağlayan ve film izleme edimi içinde olunduğunu unutturan saydam yapı, izleyicide hoşlanma duygusu yaratılması gibi klasik anlatı yapısının kendine içkin niteliklerini barındıran hareket imajların olduğu filmlerle çok sık karşılaşılmaktır. Bunun yanı sıra aynı filmler zaman imajın tamamen harekete bağlı akan bir zaman kurgusu yerine kahramanın hayallerinde, düşlerinde, içsel yolculuklarında, paralel evrenlerde ve zamanlarda, fiziksel dünyanın gerçekliğinden uzaklaşan, gerçek ile hayali olan arasındaki sınırın ayırt edilemez şekilde muğlaklaştığ1 
anlatı yapısı gibi özelliklerini de hikayenin anlatımında kullanabilmektedir. Bu bağlamda çalışmamızda ele alınan filmlerin hem hareket imaj hem de zaman imaj sinemasından izler taşıdıkları düşünülmektedir.

\section{"Big Fish" ve "Life of Pi" Filmlerinde Sorgulanan Gerçeklik}

Bazen insan, yaşadığı tecrübeleri zihninde farklı biçimlerde yeniden tasarlayarak kendi alternatif gerçekliğini hayali olarak kurgulamaktadır. Çoğu zaman bu, olumsuz deneyimlerin bireyin psikolojisine vereceği zararı hafifletmek içindir. Anılarına dönen insanlar yaşananları olduğu gibi değil zihinlerinde dönüştürdükleri şekliyle hatırlayabilmektedir. Tim Burton'ın yönettiği "Big Fish" filminde, ana karakterin hayal dünyası ile gerçeklik arasındaki sınırı bulanıklaştıran bir hikaye vardır. Filmde, Edward Bloom karakterinin yaşamına dokunan herkesle, kendi kişisel tarihine ilişkin hikayeler paylaştığı ve fanteziyle gerçeğin birbirine karıştığı bir anlatım biçimi sürdürülmüştür. Ancak filmin sonuna kadar bu masalsı hikayelerin karakterin gerçek yaşam öyküsü mü yoksa tamamen hayali hikayeler mi olduğu anlaşılmaz. Bu kafa karışıklığ durumunu, Bloom'un oğlu olan Will karakterinin babasının hikayelerinin gerçekliğine inanmayışı beslemektedir. Filmin sonu, Bloom'un anlattıklarının, yaşadığı gerçek olayların daha renkli ve abartılı bir yaklaşımla yeniden inşa edilişi olduğunu gösterir izleyiciye. Will, filmin sonunda, babasının cenazesine katılan arkadaşlarını gördüğünde, küçük bir şaşkınlık yaşar. Dinlediği hikayelerde olduğu gibi yapışık bedenleri olmasa da Uzak Doğulu ikiz kadınlar, bir dev değilse de normal insanlardan çok daha iri olan Karl ve kurt adam olmadığını bildiği sirk patronu, Edward Bloom'un hayatının gerçek anılarını paylaştığı kişiler olarak dururlar karşısında.
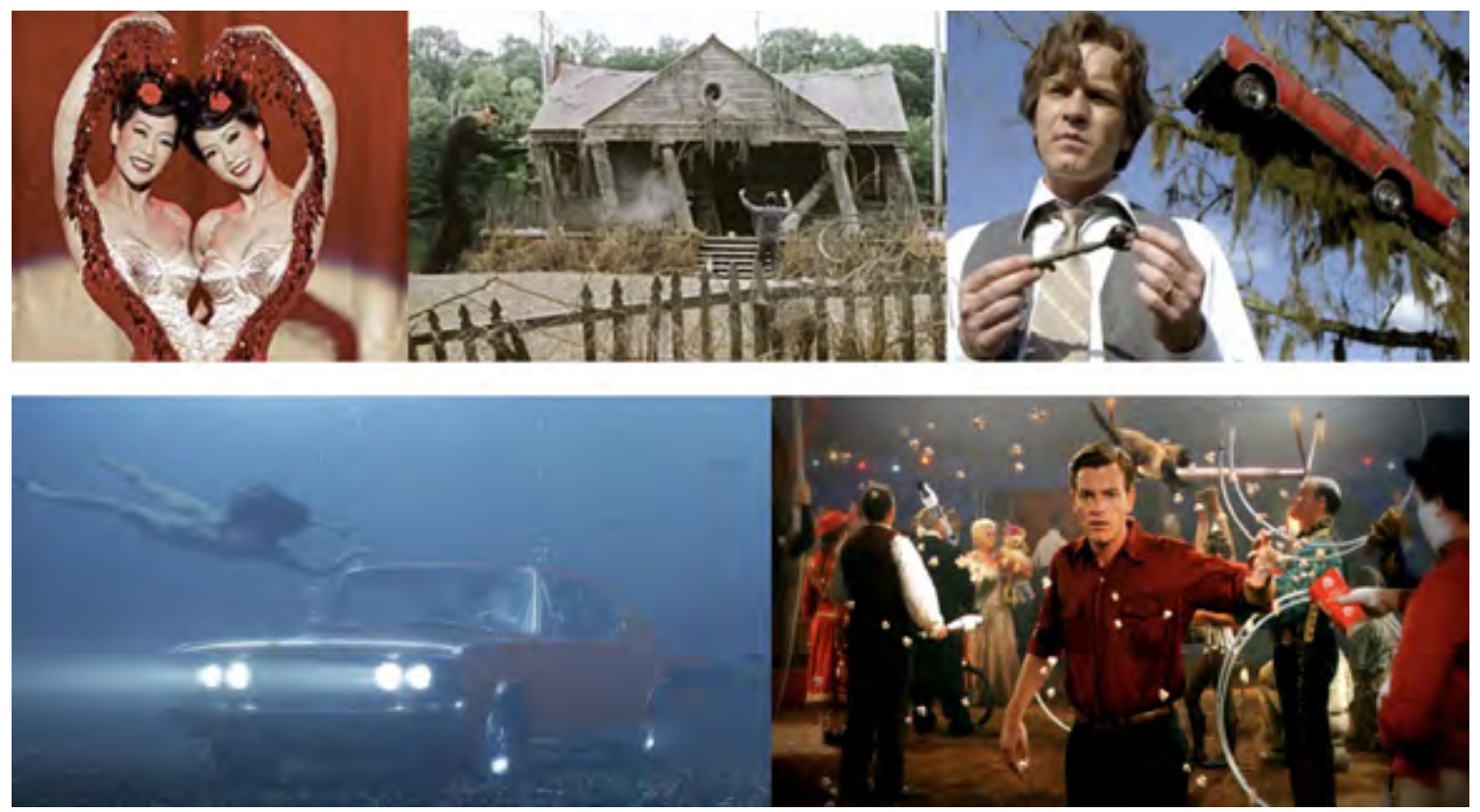

Görsel 1. "Big Fish" (2003) filminde, dijital görsel efektler kullanılarak ana karakterin yaşam hikayesini zihnindeki hayali gerçekliğiyle yansıtan imajlardan örnekler

Orr'un ifadesiyle, "modern film, bilinçten daha öteye gider. Buradalığın ve yokluğun, gerçeğin ve hayali olanın sinematik çerçevenin içinde birlikte varolduklarını açıkça gösterir. Aslında gerçek ile hayali olan arasında kesin bir sınır yoktur" (1997: 117). Yazarın işaret ettiği 
gibi filmde, Bloom'un gerçekten yaşadıkları ile hayalini kurduğu şeyler arasında net bir sınır bulunmaz. Sartre'a göre, "Yaratıcı edim aynı anda hem yapıcı, hem ayırıcı, hem de yıkıcıdır." Kendi mevcudiyetini akılda kurabilmek için mevcut olanı hem zaman hem de mekan olarak yıkar (Orr, 1997: 117) Bu yaklaşımdan hareketle Bloom karakterinin filmde kendi mevcudiyetini gerçeküstü ve düşsel bir gerçeklikle aklında ve anlatılarında kurarken rasyonel gerçekliği hem zaman hem de mekan olarak yıktığını söyleyebiliriz. Morin'in ifadesiyle "İnsan uyanıkken bile etrafı bir imgeler bulutuyla çevrilidir." (2005: 210). Bu bağlamda gerçeklik ve kurmacayı birbirinden net çizgilerle ayırmak sanıldığı kadar kolay değildir. Žižek'in perspektifinden baktığımızda, "Kurmaca ve fantezi daima 'gerçekliğin' içinden gerçer. Fantezi gerçeklikten kaçmaya yarayan hayali bir yanılsama değildir, toplumsal yaşamın asıl temelidir" (Akt. Diken ve Laustsen, 2014: 27).

Filmde izleyicinin tanık olduğu anılar için gerçeklik ve kurmaca ayrımı belirsizdir. Filmin anlatım yapısı bu ayrımı yapmayı zorlaştırmaktadır. Karakterin anıları üzerine kurguladığ1 fanteziler, Žižek'in de üzerinde durduğu gibi gerçekliğin içinden geçmektedir. $\mathrm{Bu}$ bağlamda yönetmen fantezi ve gerçeklik ayrımını sinematografik tercihlerle netleştirmez. Hayali ve gerçek olan arasında iki uçlu bir anlatım sergilemez. Kısaca sinematografik yapıda anlatıyı gerçek ve düşsel olan şeklinde ikiye bölmez.

Bu bağlamda Yönetmen Tim Burton, pek çok filminde olduğu gibi bu filminde de dijital görsel efektleri hikayeyi destekleyecek şekilde ve sınırlı düzeyde kullanmıştır. Yönetmen filmlerinde, pratik uygulamalarla oluşturabileceği sahneler için dijital efekt kullanmayı tercih etmez. Burton, Bill Desowitz'e (2003) verdiği röportajda, CGI (bilgisayar ürünü görüntü) etkisini asgari düzeyde uyguladıklarını ifade ederken dijital efektleri, elde etmek istedikleri görüntüyü sağlamlaştırmak için uygulamayı temel aldıklarını söylemektedir. "Big Fish" filmini çekerken tercih ettiği yaklaşımla ilgili, "Hayatta neyin doğru neyin doğru olmadığını ve olayların nasıl algılandığını gösteren gri bir alan var. Bu yüzden görsel olarak gerçeği ve fanteziyi hafifçe birleştirmek istedim. Böylece gerçeğin içine girip çıkan bilinçli bir yol aktı." İfadelerini kullanmakta ve "her şeyin soyut görüntüleri ve gerçek duyguları biraraya getirmek" için olduğunun da altını çizmektedir (Desowitz, 2003).

Tim Burton'ın yönettiği “Big Fish” (Büyük Balık, 2003) filminin gerçek ve hayali olan arasında kurduğu bağla benzer bir yaklaşım Yann Martel'in aynı adlı romanından sinemaya uyarlanan, Ang Lee' nin yönetmenliğini üstlendiği “Life of Pi” (Pi'nin Yaşam1, 2012) filmi örneğinde de karşımıza çıkmaktadır. Film, Pi karakterinin Avrupa'dan gelen bir yazara yaşam öyküsünü anlatması üzerine kurgulanmıştır. Pi, Hindistan'da hayvanat bahçesi işleten bir ailenin iki oğlundan küçük olanıdır. Babasının hayvanat bahçesindeki hayvanları satıp Kanada'ya yerleşme kararı almasıyla, 16 yaşındaki Pi ve ailesi hayvanlarla birlikte bir Japon kargo gemisinde yolculuğa çıarlar. Gece saatlerinde büyük bir fırtınaya yakalanan gemi batar. Gemiden sadece Pi, hayvanat bahçesinde Richard Parker adını verdikleri Bengal kaplanı, yaralı bir zebra ve vahşi bir sırtlan kurtulur. Bengal kaplanı ve sırtlanı deniz tuttuğu için çok fazla hareket edemez durumdadırlar. Daha sonra bir muz demetine sığınmış olan anne orangutanın da hayatta olduğunu farkedip filikaya çıkmasına yardım eder Pi. Filikadaki ilk gün sırtlan yaralı zebraya saldırır ve onu yemeye çalışır. Anne orangutan bu duruma karşı koyup sırtlana bir tokat atar, ancak önce şaşkına uğrayan sırtlan, sonra anne orangutana da saldırarak onu ve yaralı zebrayı öldürür. Deniz tuttuğu için güçsüz kalan Bengal kaplanı, kendine geldiğinde, sırtlanı öldürür. Filmde kaplan Richard Parker ile Pi'nin, Pasifik Okyanusu'nun ortasında bir filikada hayatta kalma mücadelesi anlatılır. 


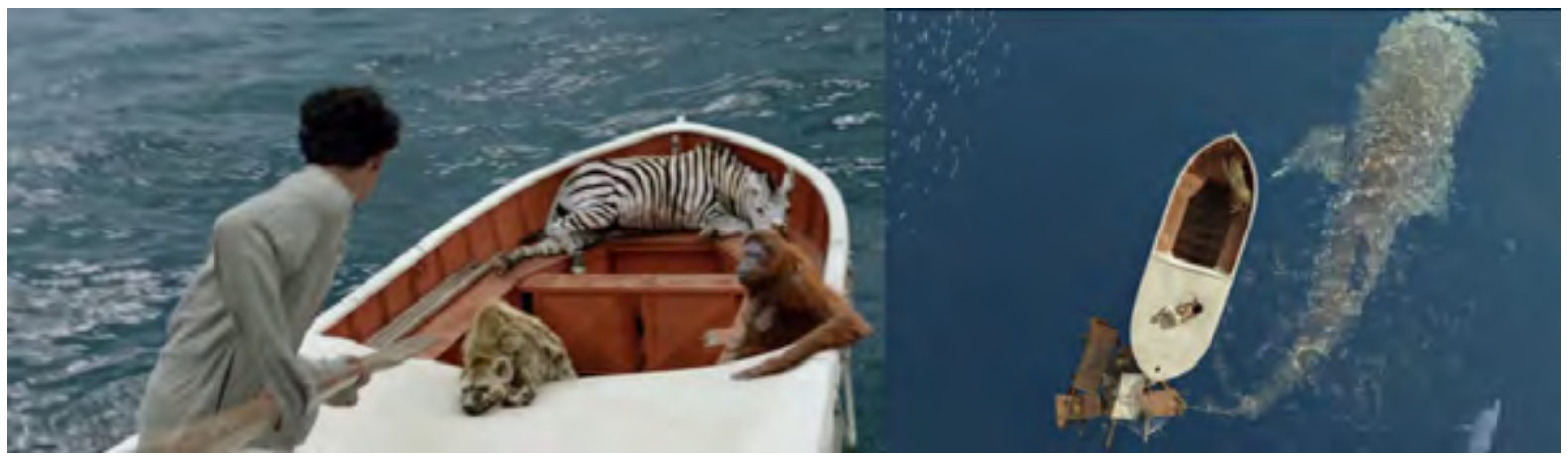

Görsel 2. "Life of Pi" ( 2012) filminde, Pi'nin zihninde kurguladığı ancak izleyiciye gerçekmiş gibi yansıtılan imajlar

Pi'nin Avrupalı yazara anlattığı ve hareketli imajlarla filmin izleyicisine yansıttığ bu hikaye, küçük tuhaflıklarına rağmen ilk başta oldukça gerkçekçi ve inandırıcı gelir. Ancak film ilerledikçe karşılaşılan imgeler ve hikayenin evrildiği anlatı, izleyiciyi kuşkuya düşürür nitelikte kurgulanmıştır. Filmin zamansal düzleminde aylar geçtikten sonra, uzaktan gördükleri gemi, Pi'nin bütün uğraşlarına rağmen onları farketmez ve son kurtuluş umutları da uzaklaşıp gider. Pi'nin büyük bir hayal kırıklığı yaşamasına ve içinde beslediği umudun azalmasına neden olan bu olayın ardından, hava iyice karardığında, gözlerini dikmiş uzaklara bakan Richard Parker'ın bakışlarını sorgular Pi ve ona nereye baktığını sorar. Richard Parker'ın başını çevirdiği yöne, denizin derinliklerine bakan Pi'nin ardından, Parker'ın bakışını yakın planda gösteren yönetmen, bu bakışa yansıyanları takip eder. Dijital görsel efekt uygulamalarıyla kurgulanan görüntüler, Pi'nin zihninin götürdüğü bulanıklaşan alana taşır izleyicinin bakışını. Kamera denizin derinliklerine uzandıkça Pi'nin zihnindeki bulanıklaşan alan netleşmeye başlar. Karakterin hayali evreninde gerçekliğin izlerini yansıtır yönetmen. Kırmızı bir balık büyük bir balığa saldırır, kurtulmaya çalışan büyük balığın bedeni hayvanat bahçesindeki hayvanların bağlandığı bir alana dönüşür. Bağdan kurtulan hayvanlar denizin derinliklerine savrulur. Kamera derin sularda ilerledikçe parıldayan şekillerin birleşmesiyle oluşan görüntüde, Pi'nin annesinin yüzü gösterilir. Ardından kameranın daha derinlere inen bakışı izleyiciyi denizin derinliklerinde yatmakta olan gemi ile buluşturur.

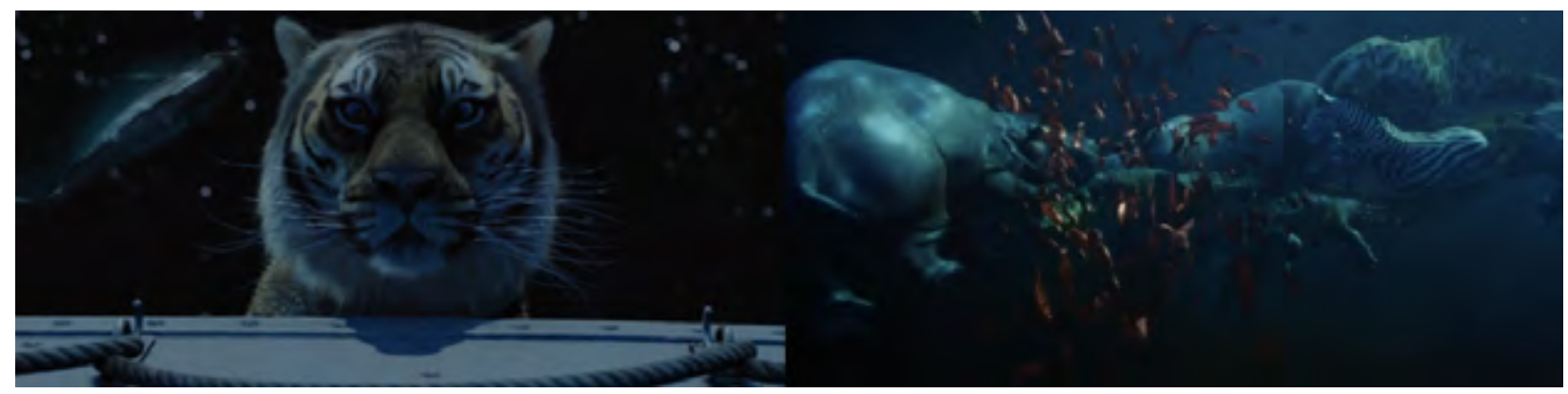




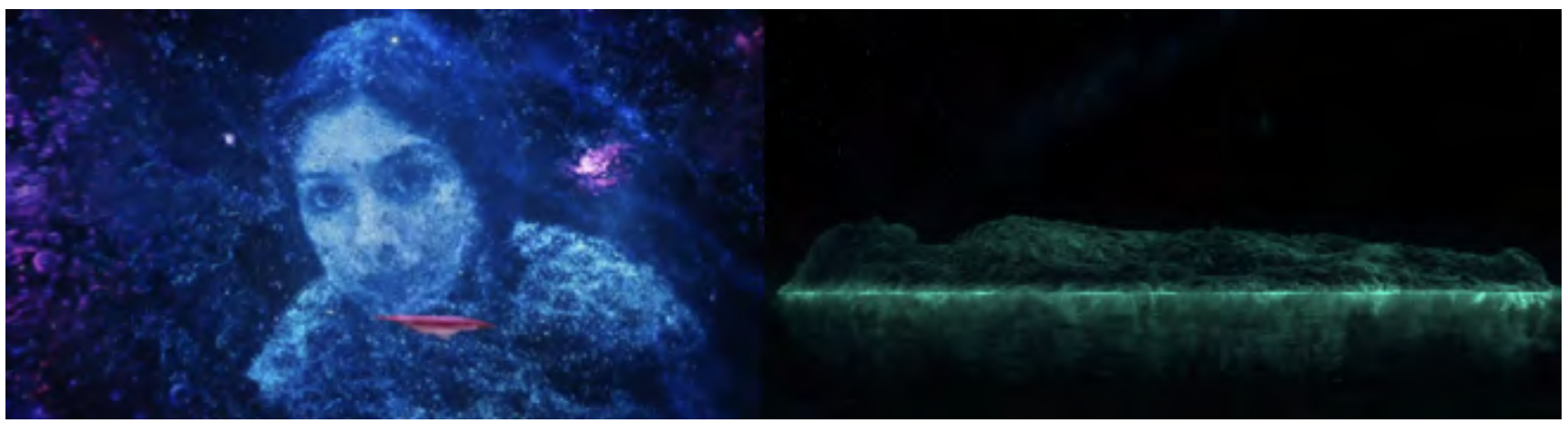

Görsel 3. "Life of Pi" (2012) filminde, Pi'nin zihnindeki hayali evrende, hikayedeki gerçekliğin izlerine rastlanan imajlar

Karakterin yaşadığı bütün bu kafa karışıklığı ve hayali olanla gerçekliğin izlerinin muğlaklaştığ1 görüntülerin ardından filikanın sürüklenerek geldiği ve Pi'nin kurtulma umuduyla sığındığı adanın sekansın sonunda "ölüm adası", olarak betimlenişi, izleyiciyi hikayenin gerçekliği konusunda kuşkuya düşürür. Filmin sonuna yaklaşırken Pi ve Richard Parker'ın bulundukları filika karaya vurur. Pi'yi kurtaran adamlar gelmeden Bengal kaplanı Parker oradan uzaklaşır. Çok güçsüz kalan Pi, hastanede tedavi altına alınır. Batan Japon kargo gemisinin sigorta şirketi memurları onu hastane odasında ziyaret eder. Oluşturacakları rapor için geminin batma hikayesini ondan dinlemek isterler. Pi, Avrupa'll yazara anlattığ 1 ve film boyunca izleyicinin tanık olduğu hikayenin aynısını sigorta memurlarına da anlatır. Ancak sigorta memurları, daha "gerçek" bir hikayeye ihtiyaçları olduğunu söyler. Bunun üzerine Pi daha farklı bir hikaye anlatır. Bu ikinci hikayeyi Pi'nin anlatımıla dinleriz, hikaye hareketli imajlara dönüştürülmez:

Dört kişi kurtulduk, aş̧̧ı ve denizci zaten filikadaydı. Aşçı bir can simiti atıp beni filikaya çekti ve annem bir muz demetine tutunup filikaya ulaştı. Denizci düşerken bacağını çok kötü kırmıştı, bacak mikrop kaptı. Onu kurtaramadık, öldü. Aşçı ilk balı̆̆ını yakaladığında ben neyle yakaladığını anlamamıştım, ama annem anlamıştı. Annemi hiç bu kadar kızgın görmemişsim. Sızlanmayı kesip mutlu ol dedi, ya yiyecek buluruz ya da ölürüz, hepsinin amacı bu. Neyin amacı buydu dedi annem. Zavallı çocuğun ölmesine, yem olsun diye mi izin verdin, seni canavar! Aşçı çok kızdı, yumruğunu kaldırıp anneme yöneldi ama annem yüzüne o kadar sert bir tokat attı ki, şoke olmuştu. Annemi orada öldüreceğini düşündüm, ama yapmadı. Bir hafta sonra, benim yüzümden, aptal bir kaplumbağayı tutamadığım için, elimden kayıp kaçtığı için aşçı başıma vurdu, dişlerim kenetlendi. Bir daha vuracak sandım ama annem yumruklarıyla ona vurmaya başladı, canavar diye bağırıyordu. Bana sandala gitmemi söyledi. Sandala atladım ve geri döndüğ̈̈mde bıçağın çıktı̆̆ını gördüm. Yapabileceğim bir şey yoktu, başımı da çeviremedim, cesedini filikadan attı, sonra köpek balıklarn geldi ve onlar annemi... Gördüm! Ertesi gün onu öldürdüm. Bıçağı kenarda bırakmıştı ve ona, onun denizciye yaptı̆̆ı şeyi yaptım. O kadar kötü bir adamdı ki, ama yine de, içimdeki kötülüğ̈̈ çıkardı. Bununla yaşamak zorundayım. Bir filikada yalnızdım, Pasifikte sürükleniyordum ve kurtuldum.

Pi'den iki hikaye dinleriz, ilki filmin bütününde hareketli imajlarla anlatılan kaplanlı hikayedir. İkincisi ise görsellere yansittlarak betimlenmeyen, sadece Pi'nin sözcüklerinden dinlediğimiz ama bizi ilkine oranla çok daha fazla rahatsız eden, annesiyle olan hikaye. Hikayeleri eşleştirdiğimizde Pi'nin ilk hikayede yaralı denizci yerine, yaralı zebrayı; aşçı yerine sırtlanı, annesi yerine de anne orangutanı konumlandırdığını anlarız. Bengal kaplanı ise hayatta kalma savaşı 
veren Pi'nin ta kendisidir. Karakter, yaşadığı acı tecrübeleri hayatı olumlamak ve daha yaşanılası bir dünya yaratmak amacıyla kendi zihninde farklılaştırarak, psikolojik olarak üzerindeki tahribatı daha az olabilecek bir hikayeye dönüştürmüştür.

Bu hikaye anlatımında yönetmenin hayali hikayeyi görsellerle yansıtırken asıl hikayeyi görüntüye dönüştürmeyişi düşündürücüdür. Filmin sonunda Pi'nin Avrupalı yazara sorduğu soruyu getirir akla bu durum: "iki hikaye anlattım, ikisi de geminin neden battığını açıklamıyor değil mi, hiç kimse gerçek olup olmadıklarını da ispat edemez. İki hikayede de gemi batıyor, ailem ölüyor ve ben acı çekiyorum. Sen olsan hangisini tercih ederdin?" Yönetmen de tıpkı filmdeki yazar gibi kaplanlı olan hikayeyi mi tercih etmektedir? Eğer öyleyse bu tercihin nedeni, filmde de belirtildiği gibi kaplanlı olanın daha iyi bir hikaye olması mıdır? Filmin okyanusta geçen bütün sahnelerinin bir havuzun içinde çekildiği ve hayvanlar, okyanustaki dalgalar, ölüm adası ve daha pek çok şeyin dijital ortamda tasarlandığı düşünüldüğünde, belki de yönetmen, izleyicilerin görüntüleri takip ederek şahit oldukları bu hikayenin aslında gerçeğinden ayrılan yönleriyle hayali unsurlar taşıdığını ima etmektedir. Bu yaklaşımın yanı sıra, okyanusun ortasında vahşi hayvanlarla genç bir çocuğun yaşam mücadelesini filme yansıtmak, bu vahşi hayvanların ne kadar eğitimli olurlarsa olsunlar, bu koşullarda kolaylıkla kontrol edilemeyecekleri gerçeğinin de yapımcıları ve yönetmeni dijital görsel efekt uygulamalarına zorunlu olarak yönlendirmiş olduğunu da düşünebiliriz. Filmin görsel efekt tasarımcısı Bill Westenhofer bu konuda, " Bilgisayarda üretilmiş bir kaplan gerçekten bu filmi yapmanın tek yoluydu. Animatronik (robotik olarak kontrol edilebilen mekanik kukla) bir kaplan yapamazdık ve film boyunca gerçek bir kaplanı kullanamazdık. Mükemmel eğitimli bir kaplanınız olsa bile ve stüdyoda hukuk departmanını ve sigorta şirketini o kaplanın bir çocukla etkileşime girmesine izin vermeye ikna edebilseniz bile, küçük bir teknede birlikte sıkışıp kalacaklardı ve bunun olmasına imkan yoktu. Bu yüzden bu gösteri için tamamen foto-gerçekçi bir kaplan elde etmek zorunda kalacağımızı biliyorduk ve bunu en iyi şekilde yapmak bizim hedefimizdi" (Duncan: 2013: 54) açıklamasını yapmaktadır.

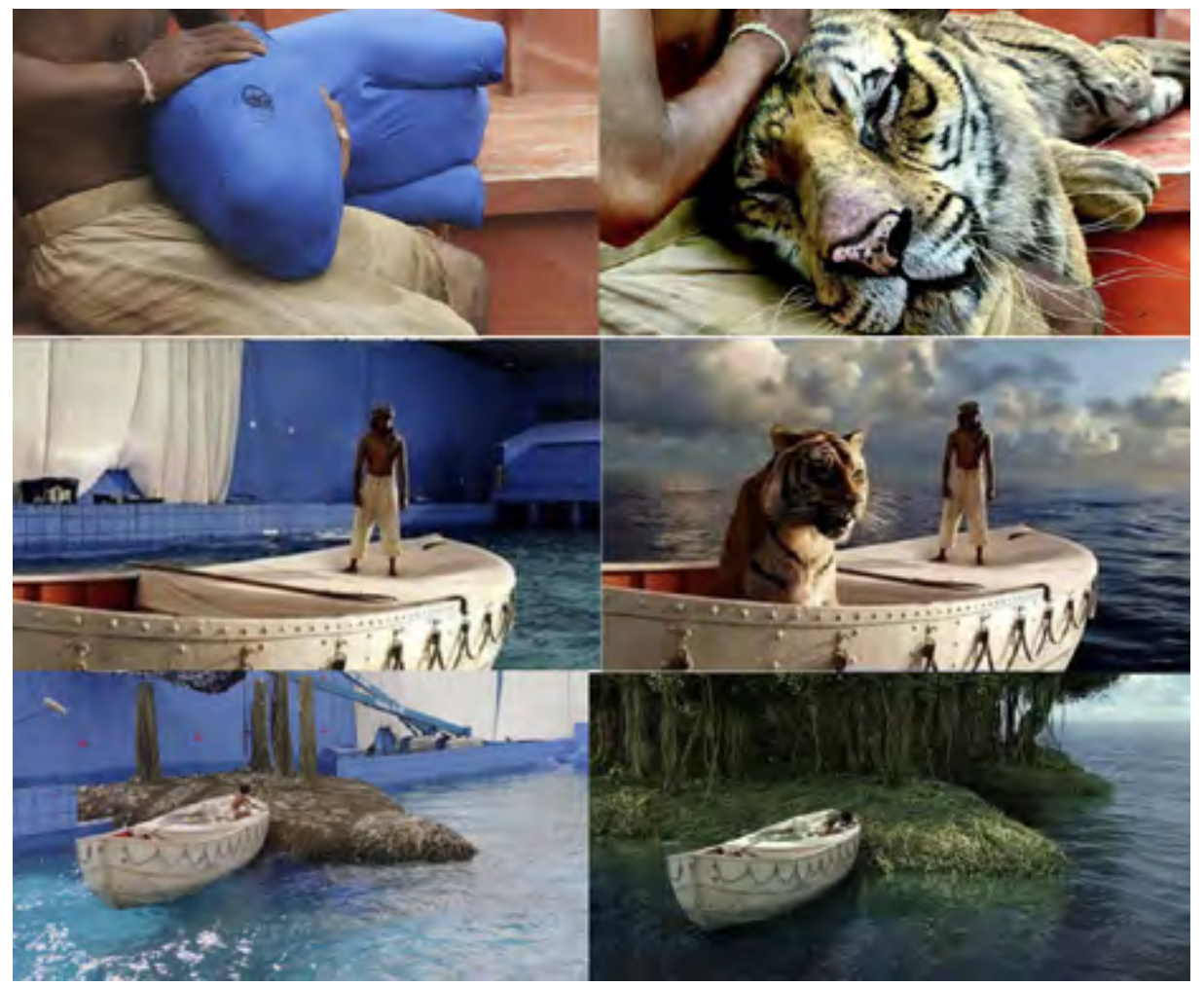

Görsel 4. "Life of Pi" (2012) filminde, CGI ile üretilen karakterin, çevre tasarımının ve görsel efektlerin görüntüye eklenmesi 
Bu bağlamda, filmin büyük çoğunluğunda kullanılan dijital görsel efekt uygulamaları, dünün görselleştirilemez olan anlatılarının bugünün teknolojileriyle hayata geçirilebilir olduğunun örneği olarak değerlendirilebilir. Bu teknolojiler nesnel gerçekliğin alternatifi olarak görülebilecek anlatıların, insanın iç dünyasında var olan düşlerin, fantezilerin, korkuların veya mitolojik anlatıların ya da metaforların sinema perdesinde görünür kılınmasını sağlamakta; duygu ve düşüncelerin ifadesinde yeni yollar üretilmesine zemin hazırlamaktadır. İnsanların zaman zaman bilinç dışı ya da bilinç düzeyinde zihninde yarattığı farklı deneyimleri, hayalleri, düşleri ya da halisülasyonları, bu filmde olduğu gibi dijital görsel efekt uygulamaları, görülebilir ve anlaşılabilir bir yapıya dönüştürebilmektedir. Bu ve benzeri dijital teknolojiler bazen Deleuze'un işaret ettiği hareket imajlardan, zaman imajlara evrilen rasyonel ve irasyonel düzeyde virtüel olanla edimsel olanın iç içe geçtiği anlatıları görünür kılabilmektedir. Gerçekliğin sineması üzerine düşünen Deleuze'e göre, "sinema bazen bize nesnel olarak gerçek ortamları, durumları ve karakterleri göstermekte; bazen de bu karakterlerin, kendilerini görme yollarını, kendi durumlarını, ortamlarını, sorunlarını gördükleri şekilde kendi karakterlerini gösterme biçimlerini, öznel olarak iddia ettiklerini göstermektedir" (1989: 149). Deleuze'ün bu yaklaşımı, incelediğimiz her iki filmde de okunabilmektedir. İki filmin de ana karakterleri yaşadıkları olay ve durumları nesnel gerçekliğe bağlı kalarak değil, kendilerini bu hikayelerin içinde görmek istedikleri şekilde yansıtmışlardır.

\section{İdeolojik Olan Toplumsal Gerçekliğin “Avatar" Filminde Yapıbozumu}

James Cameron'ın yönettiği “Avatar” (2009), dünya tarihinin inşa ettiği gerçeklik karşısında alternatif bir gerçeklik sunar izleyicisine. İçinde yaşadığımız dünyada hakimiyetini sürdüren kapitalist sistemin her koşulda kazanmanın yeni bir yolunu bulduğu toplumsal düzene alternatif olan, sistemin bütün şiddetine rağmen doğanın hakimiyetini ilan edişidir.

Filmde dijital görsel efektlerle yaratılan Pandora gezegeninin yapısını incelediğimizde, doğanın temel renkleri olan mavi ve yeşilin hakimiyetini görmemek mümkün değildir. Navi halkı da dahil olmak üzere, bitkiler, hayvanlar, kısacası tüm canlılar yeşil ve mavinin her tonu kullanılarak varedilmişlerdir. İnsanların bu alana girebilmesi için de onların bedenleriyle uyumlu bir bedene bürünmeleri gerekmektedir. Aslında uyum ve güçlü etkileşim ağ1 Pandora'nın her zerresine sızmıştır. Filmin tasarımsal yapısı, Navi halkının yaşam alanında varolabilmek için doğaya uyum sağlamak ve onunla ahenkle dansetmek gerektiğine işaret etmektedir. Doğadaki tüm canlılar arasında hatta ölü bedenlerin toprağa karışarak ağaçlarda yaşamaya devam eden ruhları arasında güçlü bir enerji akışı olduğu ve doğayı duyup hissetmenin onunla kurulan derin bağı güçlendirdiği hecelenmektedir.

Canlılar arasında kurulan bu güçlü bağ ve enerji akışı filmin tasarımsal yapısında da görselleştirilmiştir. Havada asılı duran dağlar arasındaki bağlantı, Navi halkının hayvanları kullanabilmek için onlarla kendi bedenleri arasında kurdukları bağlantı, ölen insanların bedenleriyle toprak ana ve ağaçta yaşayan diğer ruhlar arasında kurulan bağlantılar, bu güçlü etkileşimin izleri olarak tasarlanmış görünmektedir. Ayrıca Navi halkının toplu halde gerçekleştirdikleri törenlerde birbirleri ve doğayla temas halindeki ritüelleri bu uyumu yinelemektedir. 


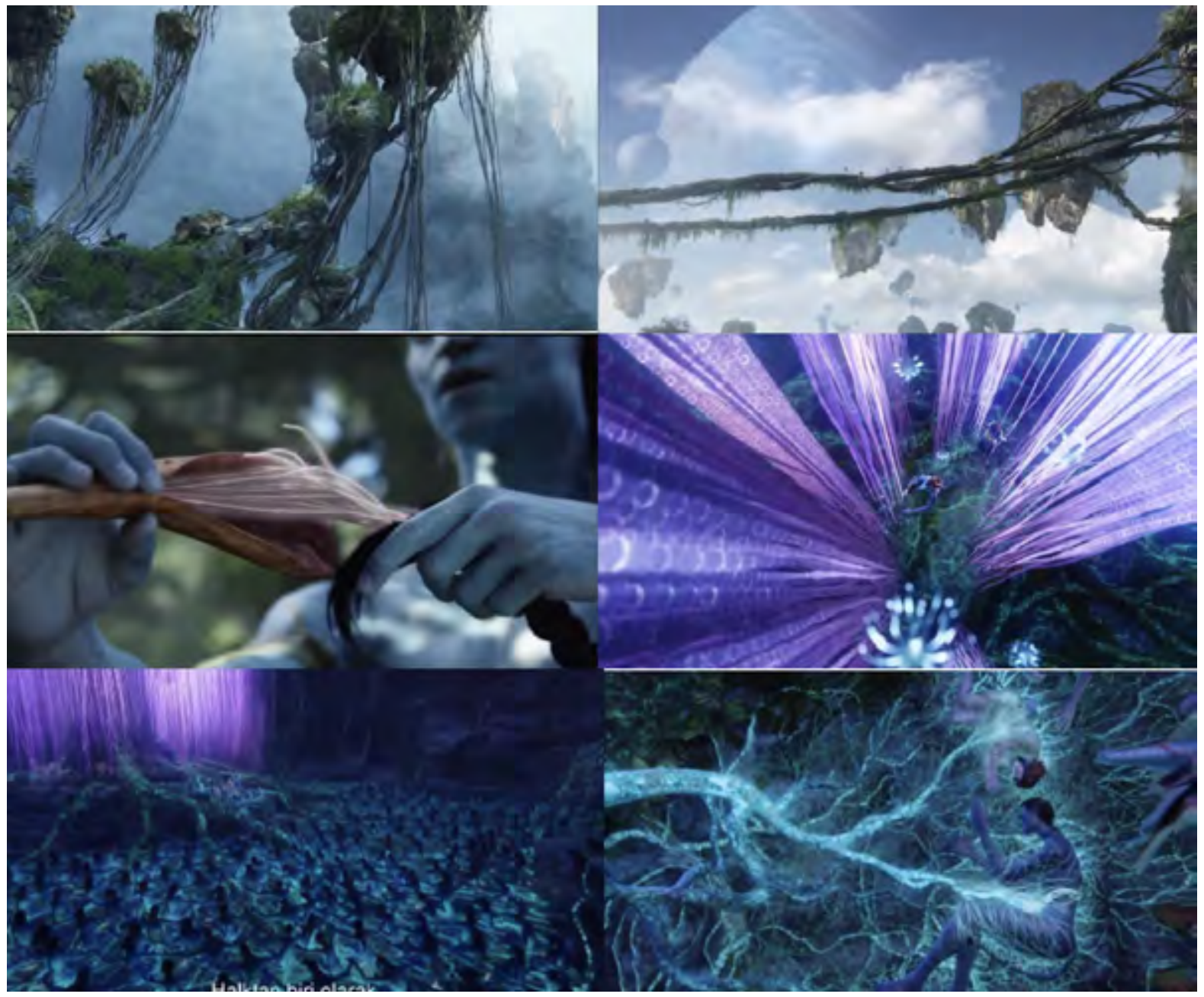

Görsel 5. "Avatar" (2009) filminde, Pandora'da inşa edilen yaşamda, canlı varlıklarn birbirleriyle kurdukları bă̆̆, enerji akışını ve uyumu gösteren, dijital görsel efektlerle oluşturulmuş planlardan örnekler

İnsanoğlunun tarihine baktı̆̆ımızda, pek çok toplum ve doğal yaşam yok edilirken tarihi metinlerde; güç ve iktidarın araçsallaştırdığı kitle iletişim araçlarında, hep insanlık için iyi ve doğru olanın yapıldığı iddia edilmiştir. Sömürülen topraklar ve o topraklarda yaşayan halklar (kendilerinin iyiliği için) öldürülmüşlerdir. Halkın refahı için, medeniyetle tanışmaları için yapılmıştır her ne yapılmışsa.

Bugün toplumsal gerçekliğin kendisinin sinemasal olduğu, yani bir kurmacaya, zorunsuz ve düşünümsel bir şeye dayalı olduğu (her şey başka türlü olabilir) şeklinde yaygın bir anlayış vardır. Toplum hiçbir zaman "olduğu gibi" mevcut değildir, sadece bir bakış aracılığıyla çarpıtıldığı şekliyle "görülür". Dolayısıyla gerçeklik ile kurmaca arasındaki ayrımı ters yüz etmek mümkündür (Diken ve Laustsen, 2014: 28). Žižek'e göre, “film sanatının en büyük başarısı, gerçekliği kurmaca anlatı içinde yeniden yaratması, aklımızı çelerek kurmacayı gerçek gibi algılamamızı sağlaması değil; aksine, gerçekliğin kendisinin kurmaca yanını fark etmemizi, gerçekliğin kendisini bir kurmaca gibi deneyimlememizi sağlamasıdır (2001: 77). "Avatar" filminin genel anlatısı da Žižek' in altını çizdiği bu noktaya taşımaktadır izleyicisini. Filmin kapitalist sistemin temsilcisi olan patron karakteri, Pandora topraklarını kendi çıkarları için istila etmelerini haklı gösterme çabasıyla, 
"Biz onlara ilaç, eğitim, yol vermeye çalışıyoruz. Ama hayır onlar çamurda yaşamak istiyorlar." ifadelerini kullanmaktadır. Devletin güç aygıtlarını temsil eden komutan karakteri ise "Burası Pandora, baylar bayanlar, bunu sakın aklınızdan çıkarmayın. Cehennem diye bir yer varsa eğer, Pandora' da tur attıktan sonra dinlenmek için oraya gitmek isteyeceksiniz. Şu çitlerin arkasında sürünen, uçan, çamurda saklanan ne kadar canlı varsa, sizi öldürmek ve gözlerinizi şekerleme niyetine yemek istiyor." sözleriyle askerlere nasıl bir yaşam alanına geldiklerini açıklamaktadır. Ana karakter Jake ise yaşanan durumu şu sözlerle ortaya koyar: “Bu işler böyle, insanlar senin istediğin birşeyin üzerinde yaşıyorsa, onları düşmana çevirirsin. Böylece istediğini almakta kendini haklı çıkarırsın." ifadelerini kullanmaktadır. Film diyaloglar üzerinden Žižek'in işaret ettiği, içinde yaşadığımız dünyanın gerçekliğinin kurmaca yapısını izleyicilerine fark ettirme çabası içinde tasarlanmıştır. Filmin biçimsel özellikleri de benzer bir noktaya taşımaktadır izleyiciyi. Örneğin giriş sahnesinde insanların kullandığı, Pandora gezegenine doğru hareket eden uzay aracının gezegene göre daha büyük algılandığı bir imgenin ardından yansıtılan görselde, aslında ilk bakışta gezegenden çok daha büyük ve güçlü görünen uzay aracının Pandora gezegeninin büyüklüğü yanında ne kadar küçük kaldığı gösterilmektedir. Filmin genelinde gezegende askerlerin ve bilim insanlarının yaşadığı alan gri ve soğuk renklerle inşa edilirken, Navi halkının yaşamını sürdürdüğü alanlar çok daha renkli ve etkileyici bir tasarımla oluşturulmuştur.

Bütün bu anlamların oluşturulabilmesi için filmde karakterlerin yanı sıra çevre tasarımı da tamamen dijital ortamda üretilmiştir. Mekan tasarımında etkileyiciçevresel efektlerle parlak bitkiler ve havada asılı duran dağlar gibi doğal yaşam vurgusunu artıran tasarımlar oluşturulmuştur. Bilgisayar grafiklerinin sahne uzantıları üretiminde kullanımıyla dijital ortamda üretilen sahneler, bütünün ayrılmaz bir parçası halini almıştır (Chopine, 2011: 8).

"Avatar" filmiyle yeni bir teknoloji ürettiklerini söyleyen yönetmen James Cameron, filmlere her zaman uygulanabilen özel efekt tasarımını işaret ederek filmde makyaj efekti uygulayarak çekim yapabileceklerini, ancak bunu tercih etmediğini söylemiştir. Maviye boyanmış aktörlerin ormanda koşuşturmalarına ilgi duymadığını, performans yakalama tekniğini kullanmak istediğini ifade etmiştir. Bunun tekinsiz vadi (uncanny valley) olarak düşünülebileceğini, ancak burada kendisinin ve ekibinin tam tersine inanarak performans yakalama tekniğinin daha gerçekçi olduğunu düşündüklerini ortaya koymuştur. Oyuncular için kafaya takılan donanımlar inşa ettiklerini; bu sayede oyuncuların koşma, yürüme, sıçrama gibi her hareketini kafalarına sabitlenmiş kameralardan kayıt altına aldıklarını belirtmiştir. Böylece yakalanan verilerin bilgisayar tarafından üretilen karakterlere eklendiğini ve performans yakalama oranının yüzde yüz on olduğunu dile getirmiştir (Discovery, 2009).

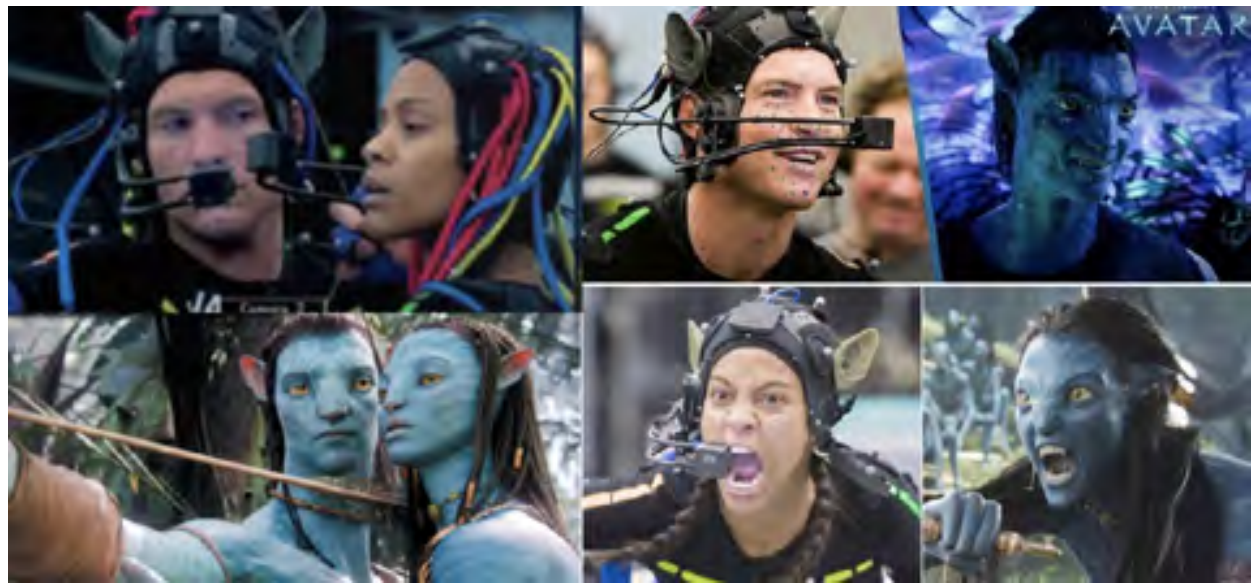

Görsel 6. "Avatar" (2009) filminde uygulanan performans yakalama tekniğine örnek görüntüler 
Sonuç olarak içinde yaşadığımız dünyanın kurmaca yapısını netleştirmek ve alternatif bir gerçeklik oluşturmak için dijital ortamda geliştirilen tasarımlar ve görsel efektler bu filmde anlamı pekiştirme değil, yaratma görevi üstlenmiştir diyebiliriz.

\section{Rüya ile Gerçek Arasındaki Sınırın Belirsizleştiği "Inception"}

Serdar Öztürk, "Sinema Felsefesine Giriş Film Yapımı Felsefe” kitabında, film yapımı felsefeninolanaklılığıüzerindetartışırkenDescartes,PlatonveNozick' indüşüncedeneylerinden bahseder ve Matrix filminin bu deneyler bağlamında okumasını yapar. Filmin kendisinin sinemanın sunduğu olanaklarla bahsedilen filozoflar gibi felsefe yapabileceğini tartışır (2018: 118-121). Bu üç düşünce deneyinin de bir anlamda "kabul edilen gerçekliğin" sorgulanması olduğu fikrinden hareketle, bu bölümde Öztürk'ün yönteminden yola çıkılarak Christopher Nolan'ın yönettiği “Inception” (Başlangıç, 2010) filmi, Descartes, Platon ve Nozick'in düşünce deneyleri bağlamında, "gerçeklik" kavramı üzerinden okunmaya çalışılmıştır.

Varoluşu sorgulayan filozoflar arasında yer alan Descartes, “Düşünüyorum öyleyse varım." önermesini, "Kendimin gerçekten var olup olmadığından nasıl emin olabilirim? Ya benim dışımda kötü cinler beni aldatıyorsa?" soruları üzerine düşünerek ortaya koymuştur. Peki ya düşüncelerimizin gerçeklikte mi rüyada mı varolduğunu bilemediğimiz koşullar altında Descartes'in yanıtı üzerinde durursak; ya düşündüğümüz ve sorguladığımızı sandığımız dünya tamamıla bir rüyanın ürünüyse? Ve bu düş dünyası zihnimizi ve paralelinde düşüncelerimizi, duygularımızı kontrol altına alarak davranışlarımızda da belirleyici olmak isteyen diş etmenlerin kontrolündeyse? Kendi gerçekliğimiz nerede başlar, nerede biter? Bu ve benzer sorular altında zihnimizi hareketlendiren "Inception" filminde rüya ile gerçek arasındaki sınır belirsizleşmektedir. Görsel efektlerle oluşturulan rüya evreninde, daha derinlere inilerek rüya içindeki rüyanın içindeki rüya gibi, iç içe açlan katmanlarda gezinen karakterler, oyunlarını birbirlerinin zihinlerindeki hayali evrenlerde oynamaktadırlar. Ancak bir noktadan sonra rüya ile gerçek arasındaki bağlantılarda silinmeler görülmeye başlar. Virtüel ile edimsel olan arasındaki gidiş gelişler karakterlerin zihnindeki edimseli muğlaklaştırır. Filmde zihnin içinde inşa edilen yaşam alanlarında seyahat halinde olduklarını bilen karakterlerin yanı sıra zihni işgal edilmesine rağmen, bunun farkında olmayıp kendi edimsel gerçekliğini yaşadığını düşünen karakterler de bulunmaktadır. İşte bu noktada Platon'un "Mağara Alegorisi"ndeki hapsolmuş halde duvara yansitılan gölgelerin gerçekliğine inanan insanların edilgen durumları gelir aklımıza.

Platon'un “Mağara Alegorisi'nde duvara yansitılan gölgelerin gerçek olduğunu sananlar, mağaradaki mahkumlar olduklarının farkında değildirler. Ancak mağaranın dışına çıkarak içerideki yanılsamaya hapsolmuşluğun farkına varanın, aslolan gerçekliği görebileceğini söyler Platon. Mağara içinde ideolojik yanılsamanın inşa ettiği gerçekliğe bağlananlar gibi, "Inception" filminde, dört katmanlı bir rüya içinde, her bir katmanda zihni farklı düzeylerde istila edilen işadamı da, rüyasında gezinen grup tarafından inşa edilen virtüel dünyada ekilen düşüncelerin, gerçek hayatında alacağı kararları etkilediğinin ve istenilen davranışı gerçekleştirmesi için güdülendiğinin farkında değildir. Bu durum, onun zihnini ve düşüncelerini manipülasyona açık ve korunmasız hale getirmiştir. Nitekim filmin sonunda rüyasında kurgulanan gerçekliğe inanır ve istilacıların istediği davranışı gerçekleştirir. Bu bağlamda film, izleyicilerine gerçek olduğuna inanılan dünyanın, gerçeğinden ayırt edilemez olan rüya alemi olabileceğini, farklı bir ifadeyle Platon'un "Mağara Alegorisi"ndeki esirler olunabileceğini göstermektedir. 
Peki zihnimizde inşa edilen yanılsamanın manipüle edilmiş bir gerçeklik olduğunun farkında olarak yine de onu yaşamayı tercih edersek? Bu durumda hayali olanın bilinçli bir tercihle kendi gerçekliğimize evrildiğini söyleyebilir miyiz? Yaşamayı tercih ettiğimiz bu sanal alan, eninde sonunda bizi edimsel olanla yüzleşmek zorunda kalacağımız bir alana çeker mi? Amerikalı filozof Robert Nozick'in "Deneyim Makinesi" olarak ifade edilen düşünce deneyinde de benzer bir soru yöneltilmektedir. Nozick, sonu gelmez zevk veren deneyimler sunabilen bir "deneyim makinesi" nin içindeki yaşamın tercih edilip edilmeyeceğini sorar. "Bilim insanlarının beyni uyarmaları sayesinde büyük bir roman yazdığımızı, arkadaş edindiğimizi veya ilginç bir kitap okuduğumuzu düşüneceğiz ve hissedeceğiz. Beynimize bağlı elektrotlarla bir tankın içinde her zaman yüzeceğiz. Yaşam boyu bu makineye bağlı kalmayı ve yaşam deneyimlerimizin baştan programlanmasını kabul eder miyiz?" (Akt. Öztürk, 2018: 119) Nozick'in iddiası deneyimler ne kadar mutluluk verici olursa olsun, böyle bir hayatın seçilmeyeceğidir. "Inception" filminin ana karakterleri ise Nozick'in düşünce deneyinde olduğu gibi hayallerini, arzularını gerçekleştirecekleri bir makineye bağlı olmasalar da, damarlarına enjekte edilen ilaçlar sayesinde uzun süren uyku halinde kalarak düş dünyalarında inşa ettikleri evrede bir ömür geçirirler. Ancak filmin sonunda bu seçimin karakterleri götürdüğü son düşündürücüdür.

Filmin ana karakteri Dom Cobb ve karısı Mal, rüya içindeki rüya kavaramı üzerine çalışırken Cobb işi zorlaştırarak daha derinlere inmek ister. Rüya aleminde saatlerin y1llara dönüşebileceğini anlayamaz önceleri. O kadar derinlerde tutsak kalırlar ki kendi bilinçaltlarının kıyılarına vardıklarında, neyin gerçek olduğunu unutmuşlardır. Bu simülatif evrende kendilerine hayali bir dünya yaratan çift, kendi arzularıyla burada 50 yıl yaşarlar. Cobb, bu yaşadıklarını, yeni rüya mimarları olan genç ekip arkadaşına anlatırken, ilk başta kendilerini tanrı gibi hissettiklerini söyler, ancak hiçbir şeyin gerçek olmadığını bildiklerini de ekler. Zaman geçtikçe Cobb için böyle yaşamak imkansızlaşırken karısı Mal onunla aynı duygu ve düşünceleri paylaşmaz. Cobb'un ifadesiyle "araf onun gerçekliği olur". Bu rüyadan uyandıklarında Mal, uyandıkları dünyanın gerçek olmadığına ve gerçekliğe dönmek için uyanmaları gerektiğine inanır. Gerçek dünyadaki evlerine dönebilmenin tek yolunun ise kendilerini öldürmek olduğunu düşünür. $\mathrm{O}$, dünyadaki çocuklarının projeksiyon olduklarını sanarak gerçek çocuklarının kendilerini diğer alemde beklediği fikrini içselleştirmiştir. Sonunda intihar ederek ölür. Ancak filmin ilerleyen bölümlerinde Cobb'un anlattığı bu hikayenin eksiklikleri olduğunu öğrenir izleyici. Arafta kaybolduklarını ve oradan kaçmaları gerektiğini düşünen Cobb, karısını bu hususta ikna edemeyeceğini anlayınca, karısının zihninin derinliklerine inerek ona bir fikir ekmeye karar verir, onun için bu her şeyi değiştirecek ufak, basit bir fikirdir: Dünyanın gerçek olmadığı fikri. "Tek kaçış yolu ölmektir”. Ancak Cobb, bu fikrin karısının aklında bir kanser gibi büyüyeceğini hesaplayamaz. Uyandıktan ve gerçek dünyaya döndükten sonra bile, o dünyanın gerçek olmadığına inanmaya devam eder Mal ve tek kaçış yolu ölümdür. Bu itirafın ardından, duyduğu suçluluktan ötürü, artık bir yıkıntıya dönüşmesine rağmen karısıyla inşa ettiği dünyaya saplanıp kalan ve onu bilinç altında yaşatmayı sürdüren Cobb, rüya içinde işleyen bilinç altında onun ölmesine izin verdiğinde film içindeki gerçek hayatına devam edebilmiştir. Ancak bu noktada, yönetmen izleyicinin gerçek dünya algısıyla oynayarak, karakterin gerçek hayatta mı yoksa rüya aleminde mi olduğu konusunu açık uçlu bırakmıştır. Cobb'un rüya aleminde mi, gerçek dünyada mı olduğunu anlayabilmek için kullandığ1 ve eve döndüğünde masanın üstüne bıraktığ1 topaç, tıpkı rüya aleminde olunduğunu gösterir gibi durmadan dönmektedir. Film topaç dönmeyi 
sürdürürken bitirilmiştir. Ancak rüyalarında çocuklarının yüzlerini göremeyen Cobb, eve döndüğünde çocukların yüzlerini görebilmiştir. Yönetmen bilinçli bir tercihle "gerçeklik" konusunu muğlaklaştırarak filmin sonunu açık uçlu bırakmıştır.

Öztürk'e göre her üç filozof da sağduyumuz ve kanaatimiz ile bildiğimizi ve hissettiğimizi zannettiğimiz gerçekliğin aslında gerçek olmayabileceğini, bir yanılsama olabileceğini bize düşündürtmektedir (2018: 120). Nolan'ın filminde bu duygu güçlü bir etkiyle izleyiciye sirayet etmektedir diyebiliriz.

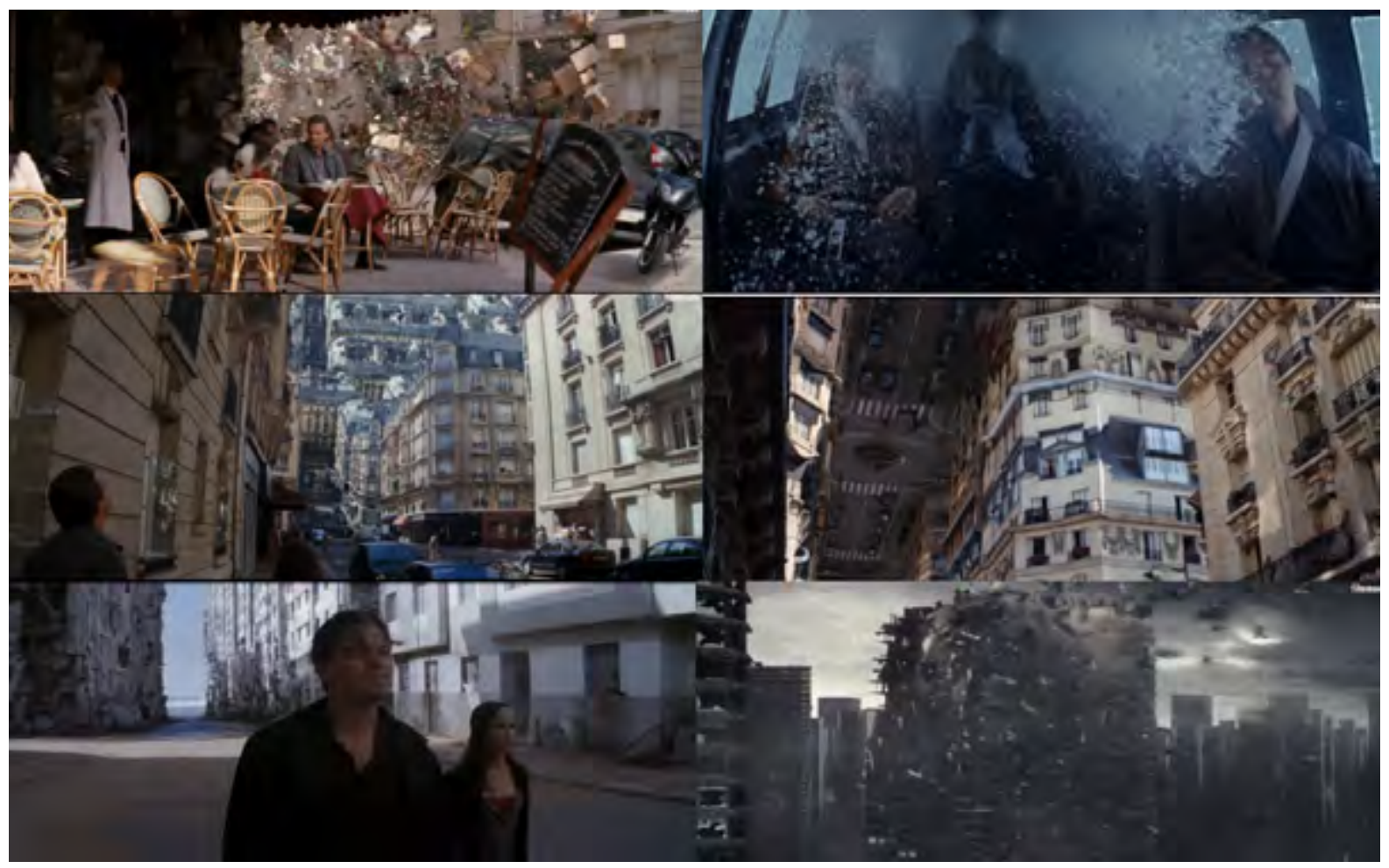

Görsel 7. "Inception" (2010) filminde görsel efektlerle oluşturulan rüya alemleri

Filmlerde herhangi bir görüntü, ister algilayan özne için mevcut gerçeğin bilinciyle ilgili olsun, ister imgelemin bir yere yerleştirdiği olmayan bir görüntü olsun, yine de doğrudandır. Görüntülerin, gerçek ve gerçekdışı nesnelerin varlıksal eşitliği; bilinci taklit eder, fakat aynı zamanda, imgesel olan doğrudan görüntü olarak yeniden yapılandırarak ya da gerçeküstü veya düşsel etkilerle tam tersini yaparak, yani görmenin değişkenliğini kullanarak algısal olanı imgesel göstererek bilinci yıkıma uğratır. Böylece Sartre'cı ayrımı tamamen tanır, fakat yine de onu allak bullak eder. Imgesel olan açık bir şekilde gerçek değildir, ancak yine de film anlatısında gerçeğin kendisi kadar doğrudan olabilir. Modern film bu belirsizlik üzerinde, sürekli bir şekilde farklı biçimlerde oynar durur. Doğrudan görüntünün sorgulanabilir olduğunu bilir. Aynı zamanda hayali olanın gerçeğin peşini bırakmadığının da farkındadır (Orr, 1997: 118).

Yönetmen Chrishopher Nolan'ın, "Inception"1 gözlemlenebilir bir gerçeklikte köklendirmek istediğini söyleyen filmin görsel efekt süpervizörü Paul Franklin, bilinçaltının gerçek dünyanın kumaşını, berrak bir rüyadaki gibi doldurmuş olarak, gerçekliğin detayını ve dokusunu sunmak istediği üzerinde durmaktadır: “Düşlerin o kadar gerçekçi görünmesini 
istedi ki, kahramanlar uyandıklarında gerçekliğin hatırasını yaşadıklarını düşüneceklerdi. Bu bilinçaltının betimlemesi Salvador Dali tasviri değildi, bu daha çok, gerçekçi manzaraları, gerçeklikten farklı, tuhaf yanlarıyla ortaya koyarak çok daha gerçekçi manzaralar çizen Giorgio de Chirico'nun imgesine benziyordu." Franklin'e göre Nolen, rüya dünyalarına yapılan önceki sinematik keşiflerin aksine, bu filmde, çoğunlukla yerinde çekim yaparak, dijital efektlerle desteklenen bilinçaltını dokunsal gerçekçilik ile tasvir etmeye çalışmıştır" (Fordham, 2010: 123). Morin'e göre, "sinema, gerçeği, gerçek dışı olanı, bugünü, gerçek yaşamı, hafızayı ve rüyayı aynı müşterek zihinsel düzeyde yeniden birleştirmektedir" (2005: 202). "Inception" filmi de tam olarak bu birleştirmeyi yapmaktadır.

\section{Sonuç}

İncelenen filmlerde yönetmenlerin görsel efekt kullanımıyla ilgili farklı tercihlerde bulundukları görülmektedir. “Big Fish" ve “Inception" filmlerinde iki yönetmenin de kamera ile çekilebilecek görüntüler sözkonusu olduğunda görsel efektlere yönelmediklerini, ancak fiziksel koşullar ya da farklı nedenlerle çekim yapmanın güçleştiği durumlarda veya anlatının bilgisayar ürünü görüntüyü zorunlu kıldığı koşullar altında görsel efekt kullanımını gündeme getirdiği görülmektedir. Burton ve Nolan'ın film çekimindeki bu yaklaşımı; kısmen "Life of Pi" filmi için geçerli olsa dahi bütünsel olarak "Avatar" filminin yapım süreci için geçerli değildir.

$\mathrm{Bu}$ filmlerde yönetlenlerin, dijital efektleri kullanma amaç, biçim ve yöntemleri değişiklikler gösterse de; bu efekt uygulamalarının, temelde filmin bütününde oluşturulmaya çalışılan anlamların yapı taşları şeklinde kullanıldıkları görülmektedir. Örneğin Tim Burton, "Big Fish" filmini yapılandırırken mümkün olduğunca dijital izler düşmemeye çalışmıştır. Karakterlerin ve ortamin analog yöntemlerle düzenlenmesiyle inşa edilmek istenen anlamın eksik kaldığ1 durumlarda, gerekli oldukça, bilgisayar ürünü görüntülere yönelmiş ve dijital görsel efektler kullanmıştır. Zihnin doğa üstü algılayışını görüntüye dönüştürebilmek, kahramanın zihinsel düzeyde yarattığı alternatif gerçekliği nesnel gerçeklikten ayrımlaşan yönleriyle ortaya koyabilmek için bu yol tercih edilmiştir, ancak genel olarak Tim Burton sinemasına bakıldığında, yönetmenin görsel efeklerdense özel efektleri tercih ettiğ i söylenebilir.

Benzer biçmide Christopher Nolan da genel olarak filmlerinde mecbur kalmadığ sürece görsel efekt kullanmaktan imtina eden yönetmenler arasındadır. Hatta filmlerinde genellikle efekt kullanımı yerine maliyeti daha yüksek de olsa gerçek yaşam koşullarını düzenleyip değiştirmeyi tercih etmektedir. Örneğin "Interstellar" filminde ana karakterin oturduğu çiftlikteki mısır tarlaları, dijital ortamda oluşturulmak yerine gerçekten ekilmiştir. Devasa toz bulutları ve kum fırtınalarını, teknik koşulları düzenleyerek doğal ortamda oluşturmayı yeğlemiştir yönetmen. Bunun için suni tozları havaya doğru uçuran büyük fanlar kullanılmıştır. Çözümlediğimiz "Inception" filminde ise arabalara çarpıp geçen tren sahnesini dijital görsel efekt kullanarak çekmek yerine, tren görünümlü bir traktör tasarlayarak bu sahneyi gerçekten çekmeyi tercih etmiştir. Ya da filmdeki patlama sahnesi için özel olarak bir yapı inşa edilmiş ve katmanlı olarak patlatılarak çekim gerçekleştirilmiştir. Sonuç olarak filmde pek çok sahne gerçek çekimlerle oluşturulmuştur. Yönetmen, insan zihninin düşsel yolculuğunu görüntüye dönüştürebilmek için mecbur olduğu sahnelerde efekt kullanmıştır. Zihnin derin sularında, karakterlerin rüyalarında gezinildiği hikayede, rüya mimarlarının inşa ettiği yaşam alanlarının, gerçek dünyadan farklılıklarını göstererek rüya aleminde olunduğunun izlerini düşebilmek ve bu doğrultuda izleyici algısında belirleyici olabilmek için ihtiyaç duyulduğu yerlerde, dijital görsel efektler kullanılmıştır. 
"Life of Pi" filminde ise, filmin hikayesinde, okyanus ortasında, küçük bir filikada, yırtıcı hayvanlarla bir arada yaşam mücadelesi veren genç bir çocuğun yaşadıkları anlatıldığı ve normal koşullarda hikayenin gerçek görüntülerle yansıtılması hayati riskleri içinde barındırdığı için filmde oldukça yoğun bir dijital görsel efekt kullanımı sözkonusudur. Filmin büyük bir bölümü bir havuzun içinde çekilerek ölüm adası, dev dalgalar gibi çevresel unsurlar, görüntülerin büyük bir çoğunluğunda yer alan Bengal Kaplanı ve diğer bazı hayvanlar, bilgisayar ürünü görüntü kullanımıyla post-prodüksiyon aşamasında oluşturulmuştur. Bahsedilen diğer filmlerle benzer şekilde, ana karakterin hayal dünyası içinde gördügü̈ halisülasyonların görselleştirilebilmesi için de filmde dijital görsel efektlere ihtiyaç duyulmuştur.

Çözümlenen filmler arasında hem karakterlerin hem de çevresel koşulların tasarlanmasında dijital görsel efekt uygulamalarının en yoğun olarak kullanıldığı film "Avatar" dır. James Cameron bu efektlerle filmde, izleyiciyi büyüleyecek, etkileyici bir evren yaratmaya çalışmıştır. Filmin senaryosunu da kaleme alan Cameron, insanoğlunun doğal yaşam üzerindeki tahribatını görünür kılmak; bu yaşamda varolan etkileşim ve iletişimin günümüz teknolojisinin sunduğu bütün olanaklardan çok daha güçlü olduğunu betimlemek için bilgisayar ürünü tasarımlarla büyülü güzellikte bir yaşam alanı yaratmıştır. Dünya içinde eşsiz güzellikte pek çok doğal alan olsa da görsel efekt kullanımıyla oluşturulan bu anlama ulaşılamayacağını düşünmektedir yönetmen. Daha önce de belirttiğimiz gibi, dijital ortamda geliştirilen tasarımlar ve görsel efektler, bu filmde anlamı pekiştirme değil, yaratma görevi üstlenmiştir. Sonuç olarak, incelenen filmlerde yoğunluğu değişen düzeylerde kullanılsa da, dijital görsel efekt uygulamaları, anlamın oluşumunda belirleyici bir rol oynamıştır. Ayrıca bütün bu filmlerde ortaya konulan alternatif gerçekliklerin görselleştirilmesinde ve filmin mesajının izleyiciye aktarılmasında pekiştirici bir etki yaratmıştır.

Bununla birlikte dijital görsel efekt uygulamalarının kendisi, başlı başına bir anlamda varolmayanı tasarlamak, zihindeki düşüncelere form vermek olarak değerlendirildiğinde, "nesnel gerçeklik" kavramı, uygulamanın varoluş amacıyla çelişmektedir. Bu bağlamda nesnel hayatta varolmayan ancak zihinlerimizi meşgul eden pek çok düşünce ve duygunun sinema filmlerinde dijital görsel efekt gibi uygulamalar sayesinde ete kemiğe bürünerek farklı oluş halleriyle görsel imgelere dönüştürülmesi, gerçeklik algılarımızı sorgulama ve yaşadığımız evrene hatta varolabilecek diğer evrenlere ilişkin yeni sorular ve cevaplar üzerine düşünmemize alanlar oluşturmaktadır.

Paradoksal olan bir başka konu ise içinde yaşadığımız dünyanın fiziksel gerçekliğinden uzaklaşırken gerçek algısı yaratabilecek teknolojilerle gerçeğe yakınlaşma, hatta gerçekle bire bir örtüşme çabasıdır. Dijital görsel efekt sanatçıları daha önce deneyimlenmemiş fiziksel sınırlılıkları aşan tasarımlarla karakterler ve mekanlar yaratırken kullandıkları 1şık filtrelerinden gölgelendirmeye, karakterlerin tasarlanmasından mekan düzenlemesine kadar pek çok detayda fiziksel gerçekliğin birebir aynısını oluşturmaya çabalamaktadır. Örneğin yaşadı ğımız dünyada varolmamış bir canlı tür tasarlandığında gerçek hayatta varolan canlıların biyolojik ve fiziksel yapılarından yola çıkılmakta ya da karakterler hareketlendirilirken gerçek yaşamdaki ışık ve gölge değerleri kullanılmaktadır. Bütün bu çabanın altında, inşa edilen gerçekliğe izleyiciyi inandırma amacının saklı olduğu düşünülmektedir.

Elbette bugün gerçek olarak kabul edilenleri, ne felsefe, ne sanat, ne de bilim "mutlak" olarak görmez. Gerçekliğin çok boyutlu ele alınması gerektiği düşüncesiyle bu gerçekliklerin farklı yönleri ortaya konulmaya çalışılır. Sinemanın, çoklu gerçekliklerin, çoklu okumalarının 
yapılabilmesine olanak sağlayan bir sanat biçimi olduğu şüphesizdir. Filmlerde gerçeğin pek çok yönünü görebilmek mümkündür. Özellikle teknolojik gelişmelerle farklı nitelikler kazanan film yapım süreçlerinde, artık dijital dünyada oluşturulan görüntülerin gerçek hayattaki kamera çekimleriyle elde edilen görüntülerin üzerine işlenebilmesiyle; duyularımızla, geçmiş tecrübelerimizle kavrayabileceğimiz, daha önceki film izleme edimlerimizden deneyimlediğimiz anlatıların kalıplarını kıran yeni anlatım biçimleri oluşturulabilmektedir. Fiziksel koşullardaki sınırlılıkların, anlatıların oluşturulmasının önünde bir engel olarak durduğu dönemleri geride bırakan sinema sektörü, geçmiş yıllarda hayal gücünün sınırlarını zorlayan hikayelerin beyaz perdeye yansıtılamadığı dönemlerden belirgin şekilde farklılaşan bir süreç içindedir.

Sonuç olarak "Sanatsal gerçeklik" kavramı üzerinde düşünürsek, gerçekliğin sanatsal olabilmesi için yansıtılan gerçekliğin aslından farklılaşan özgün formlarla yaratılması gerekmez mi? Bu durumda diğer sanat dalları gibi sinemanın yarattı̆̆ı gerçekliği sorgulamanın kendisi de başlı başına çelişkili bir yaklaşım olabilir mi? Ya da herhangi bir sanat eserinden gerçek olanı yansıtmasını beklemek yanlış bir tutum mudur? Sanat hayata estetik katmak, onu güzelleştirmek, farklı duyguları ve anlamları ortaya çıkarmak ve içinde yaşadığımız dünyayı daha yaşanılası bir yer haline getirmek için varsa; "gerçek" olanla yetinmediğimiz ve daha iyisini arzuladığımız için değil midir tüm o sanat eserlerinin varoluşu? Bu durumda bize yeterli gelmeyen bu dünyanın gerçekliğini eserlerde görme çabası üzerine düşünmek gerekmez mi? Daha iyiye daha güzele ulaşma arzusunun yanı sıra içinde yaşanılan dünyanın ruhlarda bıraktığı izleri yansıtarak görünür kılmak içinse sanat, Bazin'in de vurguladığı gibi sinemada gerçeğin kendisini değil, gerçeğin bıraktığı izi görüyor olduğumuz sonucuna varabiliriz.

\section{Kaynakça}

Bazin, Andre (1966). Çağdaş Sinemanın Sorunları. (Çev: Nijat Özön). Ankara: Bilgi Yayınevi.

Bazin, Andre (2013). Sinema Nedir? (Çev: İbrahim Şener). İstanbul: Doruk Yayınları.

Butler, Andrew. M. (2011). Film Çalışmaları. (Çev: Ali Toprak). İstanbul: Kalkedon Yayıncilik.

Burton, Tim (Yönetmen). (2003). Big Fish - Büyük Balık [Film]. USA: Columbia Pictures Corporation, Jinks/Cohen Company, The Zanuck Company.

Büker, Seçil (1989). Film ve Gerçek. Eskişehir: Anadolu Üniversitesi Yayınları.

Büker, Seçil ve Topçu, Y. Gürhan (2010). Sinema: Tarih Kuram Eleştiri. İstanbul: Kırmızı Kedi Yayınları.

Cameron, James (Yönetmen). (2009). Avatar. [Film]. UK/USA: Twentieth Century Fox, Dune Entertainment, Ingenious Film Partners.

Chopine, Ami (2011). 3D Art Essentials: The Fundamentals of 3D Modeling, Texturing, and Animation. Oxford: Focal Press.

Deleuze, Gilles (1989). Cinema 2 The Time-Image. (Translated by Hugh Tomlinson and Robert Caleta) Minneapolis: University of Minnesota Press.

Desowitz, Bill (2003). Burton Applies Light CG Touch to ‘Big Fish'. AWN (Animation 
World Network. www.awn.com. https://www.awn.com/vfxworld/burton-applies-light-cgtouch-big-fish. (Erişim tarihi: 27.12.2018).

Diken, Bülent ve Laustsen, Carsten B. (2014). Filmlerle Sosyoloji. İstanbul: Metis Yayınları.

Dinur, Eran (2017). The Filmmaker's Guide to Visual Effects: The Art and Techniques of VFX for Directors, Producers, Editors and Cinematographers. New York: Routledge.

Discovery (2009). Avatar: Motion Capture Mirrors Emotions. Youtube. www.youtube. com. https://www.youtube.com/watch?v=1wK1Ixr-UmM (Erişim tarihi: 07.01.2019).

Duncan, Jody (2013). The Calculus of Pi. Cinefex Magazine. Number: 132. (p. 52-81). Yayınlar1.

Fischer, Ernst (1990). Sanatın Gerekliliği. (Çev: Çevat Çapan). Ankara: İmge Kitabevi

Fordham, Joe (2010). In Dreams, Cinefex Magazine. Number: 123 (p. 38-69).

Güntay, Vedat (2018). Hareketli Görüntü Tasarımının Değişen Yüzü: Dijital Görsel Efekt Uygulamaları. Güzel Sanatlar Enstitüsü Grafik Anasanat Dalı Sanatta Yeterlilik Tezi. Ankara: Hacettepe Üniversitesi.

Kabadayı, Lale (2013). Film Eleştirisi, Kuramsal Çerçeve ve Sinemamızdan Örnek Çözümlemeler. İstanbul: Ayrıntı Yayınları.

Lee, Ang (Yönetmen). (2012). Life of Pi - Pi'nin Yaşamı. [Film]. USA/Taiwan/UK/ Canada: Fox 2000 Pictures, Dune Entertainment, Ingenious Media.

Lotman, Yuriy. M. (2012). Sinema Göstergebilimi. (Çev: O Ŏ̆uz Özügül). Ankara: Nirengi Kitap.

Mitchell, Mitch (2006). Visual Effects for Film and Television. Oxford: Focal Press.

Morin, Edgar (2005). The Cinema or the İmaginary Man. Minneapolis: Universityof Minnesota Press.

Nolan, Christopher (Yönetmen). (2010). İnception-Başlangiç [Film]. USA / UK: Warner Bros., Legendary Entertainment, Syncopy.

Orr, John (1997). Sinema ve Modernlik. (Çev: Ayşegül Bahçıvan). Ankara: Bilim ve Sanat Yayınları.

Öztürk, Serdar (2018). Sinema Felsefesine Giriş, Film-Yapımı Felsefe. Ankara: Ütopya Yayınları.

Sütcü, Özcan Yılmaz (2005). Gilles Deleuze'de İmge Hareketi Olarak Sinemanın Felsefesi. İstanbul: Es Yayınları.

Wright, Steve (2008). Compositing Visual Effects Essentials for the Aspiring Artist. Burlington, MA: Focal Press.

Yılmaz, Ertan (2011). Filmde Yöntem ve Eleştiri. Ankara: Deki Basım Yayım.

Žižek, Slavoj (2001). Kieslowski ya da Maddeci Teoloji. (Çev: Sabri Gürses). İstanbul: Encore Yayınları.

Žižek, Slavoj (2014). Toplumsalın Kalbindeki Film. Filmlerle Sosyoloji İçinde. İstanbul: 